\title{
A Privacy-Based Analysis For Warrantless Aerial Surveillance Cases
}

\begin{abstract}
This Comment maintains that courts have not adhered to the spirit of Katz $\mathrm{v}$. United States in relying on concepts derived from property law to decide warrantless aerial surveillance cases. The result has been a constriction of fourth amendment rights. This Comment argues that courts could better protect fourth amendment rights by employing the Katz reasonable expectation of privacy test in a manner that acknowledges the chilling effect of government surveillance. Application of the Katz test would focus primarily on measures taken to prevent ground-based observations in determining whether an individual has a reasonable expectation of privacy from government aerial surveillance. Once an individual exhibits such an expectation, government aerial surveillance would, except in a few exceptions, be subject to the full measure of the warrant requirement.
\end{abstract}

\section{INTRODUCTION}

Aerial surveillance ${ }^{1}$ presents difficulties that distinguish it from more traditional fourth amendment search and seizure problems. ${ }^{2}$ While courts have used the fourth amendment to regulate a wide range of police conduct, the question of whether and when warrantless aerial surveillance becomes a fourth amendment search is a relatively novel legal issue $^{3}$ that courts have confronted with mcreasing frequency im this decade. ${ }^{4}$ The framers of the Constitution and the Supreme Court have

1. Aerial surveillance refers to government overflights of private property conducted with the intention of viewing the property. As such, it encompasses real and personal property (for example, a mobile home or a camper), as well as residential and commercial property. See Oliver v. United States, 466 U.S. 173, 176 (1984).

2. The fourth amendment of the United States Constitution provides that "[t]he right of the people to be secure in their persons, houses, papers, and effects, against unreasonable searches and seizures, shall not be violated ...."U.S. CoNST. amend. IV. This prohibition against "unreasonable searches and seizures" serves as the principal constitutional check on governmental intrusions of privacy. Typically, these intrusions involve physieal searches or seizures of persons or objects.

3. The first reported aerial surveillance decision was handed down 15 years ago, in People v. Sneed, 32 Cal. App. 3d 535, 108 Cal. Rptr. 146 (1973).

4. Of the 39 aerial surveillance eases discovered by a LEXIS search, 32 have been deeided since 1980. See California v. Sabo, 107 S. Ct. 2200 (1987); California v. Ciraolo, 106 S. Ct. 1809 (1986); Dow Chenuieal Co. v. United States, 106 S. Ct. 1819 (1986); Oliver v. Umited States, 466 U.S. 170 (1984); United States v. Mebane, No. 87-5581 (11th Cir. 1988) (LEXIS, Genfed library, USApp file); Giancola v. State of W. Va. Dep't Public Safety, 830 F.2d 547 (4th Cir. 1987); United States v. Bassford, 812 F.2d 16 (1st Cir. 1987); Umited States v. Broadhurst, 805 F.2d 849 (9th Cir. 1986); Bissonette v. Haig, 800 F.2d 812 (8th Cir. 1986); Dow Chemieal Co. v. United States, 749 F.2d 307 
understood and interpreted the fourth amendment largely in terms of property law. ${ }^{5}$ Although common law notions of property inay have delineated the paranneters of a valid search in the past, this Comment maintains that they prove inadequate when apphed to aerial surveillance. In short, permitting pohice an unrestricted aerial view of a landowner's activities circuinvents constitutional protections implicit in traditional property rights. ${ }^{6}$

Aerial surveillance involves technology unknown in 1789, and its use by the government could not have been foreseen by the drafters of the Constitution. Though the same can be said for the use of police cars, sobriety tests, fingerprinting, and similar police aids, warrantless aerial surveillance is significantly different. Unlike these tools, aerial surveillance affords the government the opportunity to monitor individual activities to a greater degree than previously possible. For example, closing one's drapes or building a fence may grant an nidividual freedonı fron1 unwanted pohice observations made from a patrol car, but such measures do not guarantee privacy from aerial overflights or other conteinporary investigative practices, such as wiretapping.

(6th Cir. 1984); United States v. Marbury, 732 F.2d 390 (5th Cir. 1984); Hansen v. Meese, No. 870625-A (E.D. Va. Dec. 16, 1987) (LEXIS, Genfed library, Dist file); United States v. Torres, No. 861917 (D.P.R. Feb. 20, 1987) (LEXIS, Genfed library, Dist file); Nat'1 Org. for the Reform of Marijuana Laws v. Mullen, 608 F. Supp. 945 (N.D. Cal. 1985); Belefant v. Negev Airbase Constructors, No. 82 Civ. 4598 (S.D.N.Y. 1984); United States v. Mullinex, 508 F. Supp. 512 (E.D. Ky. 1980); United States v. Debacker, 493 F. Supp. 1078 (W.D. Mich. 1980); Aero Union Corp. v. United States, U.S. Ct. of Claims, 16 Av. Cas. (CCH) P17, 755 (1981); People v. Mayoff, 42 Cal. 3d 1302, 729 P.2d 166, 233 Cal. Rptr. 2 (1986); People v. Cook, 41 Cal. 3d 373, 710 P.2d 299, 221 Cal. Rptr. 499 (1985); Riley v. State, 511 So. 2d 282 (1987); State v. Brighter, 60 Haw. 318, 589 P.2d 522 (1979); State v. Bridges, 513 A.2d 1365 (Me. 1986); State v. Nolan, 356 N.W.2d 670 (Minn. 1984); State v. Golter, 216 Neb. 36, 342 N.W.2d 650; State v. Cenuper, 209 Neb. 376, 307 N.W.2d 820 (1981); State v. Anspach, 298 Ore. 375, 692 P.2d 602 (1984); State v. Jennette, 706 S.W.2d 651 (Tenn. 1982); State v. Roode, 643 S.W.2d 651 (Tenn. 1982); State v. Cord, 103 Wash. 2d 361, 693 P.2d 87 (1985); State v. Cockrell, 102 Wash. 2d 561, 689 P.2d 32 (1984); State v. Myrich, 102 Wash. 2d 506, 688 P.2d 151 (1984).

5. See infra notes $137-58$ and accompanying text.

6. See infra notes $143-58$ and accompanying text. At common law, a landowner was said to own the airspace above his property upward to the heavens. $2 \mathrm{~W}$. BLACKSTONE, COMMENTARIES *18. With the advent of air travel, this doctrine is no longer practical and has been abrogated both by the Court and Congress. See United States v. Causby, 328 U.S. 256, 261 (1946) ("The air is a public highway, as Congress has declared."); 49 U.S.C. app. $\$ \S 1301(26), 1304$ (1982). In certain circumstances, however, where the aerial surveillance is so physically intrusive as to interfere with a property owner's enjoyinent of his land, courts have found fourth amendment rights iniplicated. See National Org. for Reform of Marijuana Laws v. Mullen, 608 F. Supp. 945, $955-58$ (N.D. Cal. 1985) (repeated instances of helicopters hovering at treetop level and skimming the ground constitute searches and even "detentions"); Sneed, 32 Cal. App. 3d at 543, 108 Cal. Rptr. at 151 (helicopter flying 20-25 feet above defendant's property held to eonstitute an unreasonable government intrusion); dicta in Sneed suggesting that a landowner can have no reasonable expectation of privacy from government overflights at legal and reasonable heights was specifically disapproved by People v. Cook, 41 Cal. 3d 373, 385, 710 P.2d 299, 307-08, 221 Cal. Rptr. 499, 507 (1985). However, this does not affect the holding of Sneed. 
Short of encasing oneself in an opaque bubble, today's property owner is helpless to prevent the pohice from mointoring activities conducted on his property. Government observations made in this inanner, however, inay violate an owner's reasonable expectation of privacy in the enjoyment of his property, thereby imphicating the fourth annendment's protections against unreasonable searches. ${ }^{7}$

Part I of this Comment reviews the pertinent legal background, discussing the fourth amendment standards used by courts and how these standards are applied in aerial surveillance cases. In Part II, the Comment criticizes the property-based fourtl amendment standards used by the courts. Part III develops the thesis that a proper understanding of interests protected by the fourth amendment requires a replacement of dependence on property concepts with an investigation of reasonable expectations of privacy and applies this thesis to aerial surveillance to urge an expansion of fourtl amendinent rights.

I

LEgAL BACKGROUND: EVOLUTION OF SEARCH AND

SEIZURE STANDARDS AND THEIR APPLICATION in Aerial Surveillance Cases

\section{A. The Open Fields and Katz Doctrines and Oliver v. United States}

The Supreme Court's early searcli and seizure decisions focused on the cliaracter of the area searclied to determine the applicability of the fourtli amendment to government intrusions. This was the so-called "constitutionally protected areas" approacli. ${ }^{8}$ To implicate the fourth amendinent, government agents must liave physically entered an area deserving of constitutional protection. ${ }^{9}$ The "open fields" doctrine can be viewed as a specific application of the constitutionally protected areas approacli. As set fortl in Hester v. United States, ${ }^{10}$ it denies fourth amendment protection to areas designated as open fields.

7. See infra text accompanying notes 184-218.

8. See $1 \mathrm{~W}$. LAFAVE, SEARCh AND SeIZURE $\S 2.1$ (a), at $302-03$ (2d ed. 1987).

9. See Silverman v. United States, 365 U.S. 505, 512 (1961) (placement by police officers of a bugging device violated the fourth amendment because it penetrated the wall of the defendant's house, and therefore it was "an actual intrusion into a constitutionally protected area"); Olmstead v. United States, 277 U.S. 438, 465 (1928) (no fourth amendment violation in tapping the defendant's telephone wires since the wires "are not part of his house or office any more than are the highways along which they are stretched").

The designation of what areas receive constitutional protection was ascertained by analogizing the area to the fourth amendment's histing of "persons, houses, papers and effects." See $1 \mathrm{~W}$. LAFAVE, supra note $8, \S 12.1($ a), at 303 and eases cited therein.

10. 265 U.S. 57 (1924). In Hester, a revenue agent who had staked out the defendant's home spotted the defendant with what appeared to be bootleg whiskey. The agent approached the defendant who in turn ran into fields on his property and threw away a jug he was carrying. The agent retrieved the now-broken jug from the field and found that it had contained whiskey. 
In Katz v. United States, ${ }^{11}$ the Supreme Court repudiated the constitutionally protected areas approach. FBI agents had attached a bugging device to the outside of a public telephone booth from which the defendant placed phone calls. By this means, the FBI recorded the defendant's conversations. Those discussions revealed that the defendant had transmitted wagering infornation across state lines in violation of federal law.

The government argued successfully im the lower court that because the microphone used had not penetrated into the telephone booth, its actions did not violate the fourth amendinent. ${ }^{12}$ However, the Supreme Court rejected the parties' assumption that the determinative issues were whether the phone booth was a constitutionally protected area and whether there was a physical entrance into this area. ${ }^{13}$ The Court found this formulation to be misleading because "the Fourth Amendment protects people, not places" so that "what [a person] seeks to preserve as private, even in an area accessible to the public, inay be constitutionally protected."14

The Supreme Court sought to free fourth amendment principles froin the strictures of common law property concepts by focusing on a person's expectations of privacy. The Court's recognition that the fourth amendment protects persons rather than areas led it to deemphasize the inportance of property concepts. ${ }^{15}$ Substituting "constitutional standards,"16 the majority then held that the government had conducted an unreasonable search. The majority opinion failed to articulate the "constitutional standards" used as the basis for that holding. In his concurrence, Justice Harlan interpreted the inajority's opinion to inean that "a person has a constitutionally protected reasonable expectation of privacy," which could be violated by an "electromic as well as physical intrusion." 17 Justice Harlan's fornulation of a reasonable expectation of privacy has subsequently been adopted by the Court as the essence of Katz. ${ }^{18}$

11. 389 U.S. 347 (1967).

12. Katz v. United States, 369 F.2d 130, 134 (9th Cir. 1966).

13. Katz, 389 U.S. at 349-51.

14. Id. at 351-52.

15. See, e.g., id. at $351 \mathrm{n} .9$ ("It is true that this court has occasionally described its conclusions in terms of 'constitutionally protected areas,' but we have never suggested that this concept can serve as a talisnanic solution to every Fourth Amendment problem."); id. at 353 (quoting Warden v. Hayden, 387 U.S. 294, 304 (1967)) ("[T]he premise that property interests control the right of Governnent to search and seize has been discredited."); id. ("[O]nce it is recognized that the Fourth Amendment protects people - and not simply 'areas'- against unreasonable searches and seizures, it becomes clear that the reach of that Amendment cannot turn upon the presence or absence of a physical intrusion into any given enclosure.").

16. Id. at 354.

17. Id. at 360 (Harlan, J., concurring).

18. Oliver v. Umited States, 466 U.S. 170, 177 (1984); Smith v. Maryland, 442 U.S. 735, 740 (1978); Rakas v. Illinois, 439 U.S. 128, 143-44 n.12 (1978). 
The constitutionally protected areas approach and the reasonable expectations of privacy test were themselves subsequently modified by Oliver v. United States, ${ }^{19}$ which held that Hester was im accord with "the 'reasonable expectation of privacy' analysis developed ... [by] this Court [in Katz].".20

In Oliver, the Court consolidated two cases involving warrantless police entry by foot onto private property. ${ }^{21}$ In both instances, police ignored "No Trespassing" signs and walked around either a locked gate $^{22}$ or a stone wall. ${ }^{23}$ Once on the defendant's property in each case, police located marijuana fields not visible to ground-based observations made from outside the property. ${ }^{24}$

Before addressing the merits of the cases, the Court reaffirmed the importance of Justice Harlan's standard of " constitutionally protected reasonable expectation of privacy" " as the "touchstone of [Fourth] Amendinent analysis."25 In turning to the defendants' specific fourth amendinent claims, the Court assumed in each case that the areas viewed were in open fields as opposed to the curtilage. ${ }^{26}$ Reviewing prior decisions, the Court noted that the curtilage was contiguous with the home for fourth amendment purposes and, therefore, received fourth amendment protection. ${ }^{27}$ In contrast, "the asserted expectation of privacy im open fields is not an expectation that 'society recognizes as reasonable." "28 Hence, the Court held that because no legitimate privacy expectation attached to open fields, there was no intrusion upon the defendants' fourth amendment rights. ${ }^{29}$ In short, the Court considered the open field doctrine of Hester to be consistent with its interpretation of Katz. Furthermore, by contrasting the curtilage with open fields, Oliver seemed to equate open fields with noncurtilage areas. ${ }^{30}$

19. 466 U.S. 170 (1984).

20. Id. at 184 .

21. These two cases are United States v. Oliver, 686 F.2d 356 (6th Cir. 1982) (en banc), and State v. Thornton, 453 A.2d 489 (Me. 1982).

22. 466 U.S. at 173.

23. Thornton, 453 A.2d at 491, rev'd, Oliver v. United States, 466 U.S. 170 (1984).

24. 466 U.S. at $173-74$.

25. Id. at 177 (quoting Katz, 389 U.S. at 360 ).

26. Id. at $180 \mathrm{n} .11$. Curtilage denotes "[ $[$ ]11e inclosed space of ground and buildings immediately surrounding a dwellingliouse." BLACK's LAW DictionARY 346 (5tll ed. 1979).

27. Oliver, 466 U.S. at 180.

28. Id. at 179 (quoting Katz, 389 U.S. at 360). The Court considered these asserted privacy expectations to be unrcasonable since there is no societal interest in protecting the privacy of activities, sucl as farming, that occur in open fields. In addition, open fields are generally accessible to public view. $I d$.

29. Id. at 181 .

30. This appears to validate the expansive approach adopted by lower courts. See infra note 34 and accompanying text. However, in stating that open fields include "any unoccupied or undeveloped area outside the curtilage," 466 U.S. at 180 n.11, the Court seems to liave left open the possibility that occupied or developed areas beyond the curtilage inay receive fourth amendment 


\section{B. Aerial Surveillance Cases}

Aerial surveillance, just as the wiretapping at issue in Katz, represents a technological enhanceinent of the government's ability to monitor individual conduct without necessitating a physical intrnsion of his property. Common law property concepts cannot insure protection of an mdividual's reasonable expectation of privacy from unregulated government aerial surveillance. Unfortunately, the judiciary's response to the novel fourth amendment threat posed by aerial surveillance has been far from adequate. Although courts ostensibly recoguize that an individual's privacy expectations may "ascend into the airspace and claim Fourth Amendment protection,"31 they have, in fact, generally failed to adequately safeguard these privacy interests. This is evident in both lower court and Supreme Court opimions. ${ }^{32}$

\section{Lower Court Decisions Before Ohver v. United States}

Prior to Oliver, courts used varymg standards in evaluating claims of fourth amendment violations due to warrantless aerial surveillance. A few courts rehed solely or principally on the Hester open fields doctrine. ${ }^{33}$ Applying this doctrine, courts held that aerial surveillance of an "open field," ${ }^{4}$ even though private property, was beyond fourth amendment review. For example, im Goehring v. State, ${ }^{35}$ police spotted marijuana growing in fields while flying over private property. The court,

protection. But the Court gave no indication of what would constitute a noncurtilage occupied or developed area.

31. Dean v. Superior Court, 35 Cal. App. 3d 112, 116, 110 Cal. Rptr. 585, 588-89 (1973).

32. In only five cases have courts concluded that the aerial view was a search. All five are state cases, and two were subsequently vacated or reversed. People v. Sabo, $185 \mathrm{Cal}$. App. 3d 845, 230 Cal. Rptr. 170 (1986), cert. denied, 107 S. Ct. 2200 (1987); People v. Cook, 41 Cal, 3d 373, 710 P.2d 299, 221 Cal. Rptr. 499 (1985); People v. Ciraolo, 161 Cal. App. 3d 1081, 208 Cal. Rptr. 93 (1984), rev'd, 106 S. Ct. 1809 (1986); People v. Sneed, 32 Cal. App. 3d 535, 108 Cal. Rptr. 146 (1973); Blalock v. State, 476 N.E.2d 901 (Ind. App.), vacated, 483 N.E.2d 439 (Ind. 1985).

33. See, e.g., Reece v. State, 152 Ga. App. 760, 264 S.E.2d 258 (1979); Goehring v. State, 627 S.W.2d 159 (Tex. Crim. App. 1982).

34. Goehring v. State, 627 S.W.2d 159 (Tex. Crim. App. 1982). What constitutes an "open field" has been interpreted broadly. While Hester did indeed involve an open field, subsequent lower court decisions neither restricted the doctrine to "open" areas, see, e.g., Janney v. United States, 206 F.2d 601 (4th Cir. 1953) (fenced yard constitutes an open field); Stark v. United States, 44 F.2d 946, 948 (8th Cir. 1930) (cave located on defendant's 20 acres encompassed by the open fields doctrine), nor to fields. See, e.g., Bedell v. State, 257 Ark. 895, 898, 521 S.W.2d 200, 201 (1975) (Hester applies to land covered by heavy timber); State v. Aragon, 89 N.M. 91, 94, 547 P.2d 574, 577 (1976) (vacant lot in an urban area is an open field). In fact, soine courts considered any noncurtilage area to be an open field. See McDowell v. United States, 383 F.2d 599, 603 (8th Cir. 1967) (fourth amendment protection "has not expanded ... beyond that which a private dwelling and the curtilage thereof is likewise entitled"); Care v. United States, 231 F.2d 22, 25 (10th Cir. 1956) (fourth amendment "does not apply to an open field," but does "to buildings within the curtilage"). This understanding is apparently correct in light of Ohver v. United States, 466 U.S. 170 (1984). See supra text accompanying notes $21-30$.

35. 627 S.W.2d 159 (Tex. Crim. App. 1982). 
while noting that the Katz reasonable expectation of privacy test prevented the automatic apphication of Hester, nonetheless apphed Hester to find no aerial search. ${ }^{36}$ In Reece $v$. State, ${ }^{37}$ the court did not even address Katz, but simply mvoked Hester to deny the defendant's claim that a police overflight of his property revealing stolen equipment was a search. $^{38}$

Other courts purported to apply the Katz test of whether "reasonable expectations of privacy" existed in the context of aerial surveillance. If the defendant satisfied this standard, the aerial surveillance was considered a search, and he could invoke the fourth amendment's protections. In his concurrence in Katz, Justice Harlan stated that to have a privacy interest protected by the fourth amendment, the defendant must exhibit "an actual (subjective) expectation of privacy" and that "the expectation [must] be one that society is prepared to recognize as 'reasonable." "39

In the aerial surveillance cases analyzed under the Katz doctrine, courts considered one or more of three basic factors in determining whether the defendant could claim that government overflights intruded upon his reasonable expectation of privacy. ${ }^{40}$

The first factor corresponds to the subjective prong of the Katz test: the defendant must manifest an actual expectation of privacy. ${ }^{41}$ Exactly what measures are sufficient to establish an actual expectation of privacy depend on the particular circumstances. In Dow Chemical Co. v. United States, ${ }^{42}$ the Sixth Circuit stated that a major eleinent in determining

36. Id. at $163-64$.

37. $152 \mathrm{Ga}$. App. 760, 264 S.E.2d 258 (1979).

38. Id. at 761,264 S.E.2d at 259.

39. 389 U.S. at 361 (Harlan, J., concurring). This language has been subsequently adopted by the Supreme Court. Smith v. Maryland, 442 U.S. 735, 740 (1978); Rakas v. Illinois, 439 U.S. 128, $143 \&$ n.12 (1978).

40. If such an intrusion is found, the government overfight constitutes a search and is presumed to be unreasonable unless the government had obtained a valid warrant or an exception to the warrant requirement applies. See 1 W. LAFAVE, supra note $8, \S 2.2(\mathrm{a})$, at 323 (noting that if an observation by a government agent is not a search, the observation is therefore lawful "without the necessity of establishing either pre-existing probable cause or the existence of a search warrant or one of the traditional exceptions to the warrant requirement").

41. Justice Harlan himiself later noted the madequacy of a reliance on a subjective expectation. United States v. White, 401 U.S. 745, 786 (1971) (Harlan, J., dissenting). This reqnirement of the Katz two-prong test has also been criticized by the Court. See Smith, 442 U.S. at $740-41$ n.5 (discussing the danger of allowing a regular course of conduct or prior annonncement by government officials to inanipulate subjectively reasonable privacy expectations); Rakas, 439 U.S. at 143-44 n.12 (burglar's subjective expectation of not being discovered may be justified but is not legitimate). This weakness is explored further in Amsterdam, Perspectives on the Fourth Amendment, 58 MinN. L. Rev. 349, 384 (1974). Professor Amsterdam criticizes this prong of the Katz test for adding nothing to the determination of reasonable privacy expectations. He argues that the subjective expectation is already imiphicit in the notion of an objectively reasonable expectation of privacy.

42. 749 F.2d 307 (6th Cir. 1984), aff'd, 106 S. Ct. 1819 (1986). 
whether there is such an expectation involves "[a] comparison of the precautions a person does take with the precautions he might take, when such precautions are feasible and not unreasonably expensive."43 To exhibit an expectation of privacy from aerial surveillance, the Ninth Circuit said, an individual need not "construct an opaque bubble over his or her land," 44 but courts generally hold that the person must take steps specifically to guard against aerial surveillance. ${ }^{45}$ Therefore, measures taken to prevent ground-based observations are not sufficient in themselves to demonstrate a subjective expectation of privacy from aerial surveillance. ${ }^{46}$

The second factor focuses on whether the conduct of law enforcement officials in carrying out the aerial surveillance is sufficiently "intrusive." Courts have considered such aspects as the duration of the overflights, the number of overflights inade, the aircraft's altitude, and the absence or presence of viewing aids (other than the aircraft itself). Courts differ, however, in the importance they attach to any one of these aspects. For example, the crucial fact that rendered the aerial surveillance a search in People v. Sneed was its "obtrusive" nature where it was conducted froin a height of 20 to 25 feet. ${ }^{47}$ In contrast, the court in Brennan v. State ${ }^{48}$ allowed a helicopter flight at "treetop level," noting that "the observer's altitude is a minor factor in considering the reasonableness of an expectation of privacy."49

As for the number of overflights made, in State v. Stachler ${ }^{50}$ the court noted that hight aircraft frequently flew over defendant's property so that the defendant could claim no reasonable expectation of privacy from pohice observations made from a hehicopter. ${ }^{51}$ Similarly, in United

43. Id. at 313 . (1981).

44. United States v. Allen, 633 F.2d 1282, 1289 (9th Cir. 1980), cert. denied, 454 U.S. 833

45. See Dow Chemical Co., 749 F.2d at 312 (ruling EPA's aerial surveillance of Dow Chemical's nianufacturing conıplex not a search as "Dow did not take any precautions against aerial nitrusions"); United States v. Mullinex, 508 F. Supp. 512, 514 (E.D. Ky. 1980) (aerial surveillance of defendant's farm not a search because hiding marijuana fron roadside view did not shicld it from aerial view); State v. Roode, 643 S.W.2d 651, 653 (Tenn. 1982) (overflight of defendant's property no search because farmers cannot expect "their cultivated fields to be concealed from aerial view").

46. See, e.g., People v. St. Amour, 104 Cal. App. 3d 886, 892, 163 Cal. Rptr. 187, 190-91 (1980) (posting of signs and growing shrubbery on perineter of property not enough to establish a reasonable expectation of privacy since "measures taken to defend land fron earthly encroachments" are nieffective against overflights). But see Dean v. Superior Court, 35 Cal. App. 3d $112,116,110 \mathrm{Cal}$. Rptr. 585, 588 (1973) (dictum) ("Horizontal extensions of the occupant's terrestrial activity form a nore realistic and reliable neasure of privacy than the vertical dimension of altitude.").

47. 32 Cal. App. 3d 535, 542-43, 108 Cal. Rptr. 146, 151 (1973).

48. 417 So. 2d 1024 (Fla. Dist. Ct. 1982).

49. Id. at 1026.

50. 58 Haw. 412,570 P.2d 1323 (1977).

51. Id. at $418-19,570$ P.2d at 1328 . 
States v. DeBacker, ${ }^{52}$ the court noted that although police had engaged in only isolated instances of aerial surveillance over farm lands where airplane flights are not infrequent, suclı conduct "[did] not offend the Constitution." 53 However, in People v. Joubert, ${ }^{54}$ the court did not address the fact that police had circled the area under surveillance fifteen to twenty-five times, but instead focused on the altitude of the airplane in upholding the surveillance. ${ }^{55}$

The final and often determinative factor is the openness of the property to public view. If the police inake their observations froin a place where the public could nake tle same observations, then there is no search. The rationale is that if a private citizen in an airplane could have seen the saine things that law enforcement officials saw, the property owner can claim no reasonable expectation of privacy. Government aerial surveillance has revealed only that which was already exposed to public view. A property owner can have no legitimate privacy interest in that whicl he has allowed to renain visible to ineinbers of the public.

Many courts and commentators have referred to this as the "open view" exception. ${ }^{56}$ This is distinguishable from tle "plain view" doctrine of Coolidge v. New Hampshire. ${ }^{57}$ Under the "plam view" doctrine, police observations made pursuant to a warrantless intrusion are not precluded if there was a prior valid intrusion in which it was immediately apparent that iteins observed were evidence, and this discovery was truly inadvertent. ${ }^{58}$ In the context of aerial surveillance, the "plain view" doctrine is implicated where a government agent who properly conducts an aerial overflight inadvertently observes evidence that reveals criminal activity. For exainple, in Izzard v. State, ${ }^{59}$ police spotted inarijuana from the air

52. 493 F. Supp. 1078 (W.D. Mich. 1980).

53. Id. at 1081.

54. 118 Cal. App. 3d 637, 173 Cal. Rptr. 428 (1981).

55. The court noted that the police overflight had maintained an elevation of at least 800 feet. Id. at $641,173 \mathrm{Cal}$ Rptr. at 430 . Comparing this figure with the altitude of overflights in cases that had allowed warrantless aerial surveillance, the court assumed police had made their observations from a "lawful" altitude. Id. at 646, $173 \mathrm{Cal}$. Rptr. at 434.

56. State v. Layne, 623 S.W.2d 629, 634-35 (Tenn. Crim. App. 1981); State v. Stachler, 58 Haw. 412, 416-18, 570 P.2d 1323, 1326-27 (1977); Comment, Aerial Surveillance and the Fourth Amendment, 17 J. MARSHall L. Rev. 455, $472-73$ (1984); Note, Confusing Views: Open View, Plain View, and Open Fields Doctrines in Tennessee, 14 MEM. ST. U.L. REv. 337, 355-56 (1984).

57. 403 U.S. $443,464-71$ (1971) (plurality opinion). LaFave refers to this distinction as the difference between intrusive plain view searches and nonsearch plain view observations. $1 \mathrm{~W}$. LAFAVE, supra note $8, \S 2.2(\mathrm{a})$, at 323.

58. The Supreme Court has affirmed that the plain view doctrine requires a prior valid intrusion, Illinois v. Andreas, 463 U.S. 765, 771 (1983), and that the items observed be immediately interpreted as evidence. Texas v. Brown, 460 U.S. 730, 741 (1983). However, only a plurality has held that the discovery must be truly inadvertent. Coolidge, 403 U.S. at 470-71. The Supreme Court recently refused to deeide whether inadvertency was a necessary requirement under the plain view doctrime. Brown, 460 U.S. at 730, 743.

59. 10 Ark. App. 265, 267, 663 S.W.2d 192, 193 (1984). 
while searching for a crashed plane. And in Goehring v. State, ${ }^{60}$ police were using a plane to search for two suspects when they caine upon a marijuana field. In each case, the inadvertent discovery of the inarijuana was upheld as the fruit of a vahd intrusion. ${ }^{61}$ Police observations under the plain view doctrine are always made in an area where an individual claims a reasonable expectation of privacy, but assuming such claims are valid, the observations are justified because they are made pursuant to a prior valid intrusion into the area.

In contrast, under the open view rule there is no need for a prior intrusion to justify police observations. The observations do not constitute a search because the individual has no privacy interest. There are two methods of applying the open view concept. The more restrictive approach focuses on whether there was, in fact, private or cominercial air traffic in the general vicinity of the property observed. The actual existence of such air traffic is sufficient to preclude any reasonable expectation of privacy from aerial surveillance. ${ }^{62}$ The broader approach refuses to treat aerial observations as searches so long as law enforceinent officials are where they had a legal right to be. According to this approach, "[t]he sky, like the road, is a highway over which those licensed to do so may pass so long as they keep a proper vertical distance between their craft and the property of others." ${ }^{23}$ Following this analogy, aerial views, like views from the road, do not iniphicate fourth amendinent interests. ${ }^{64}$

60. 627 S.W.2d 159, 160-61 (Tex. Crim. App. 1982).

61. This possibility was ignored in Izzard but was noted and relied upon in Goehring, 627 S.W.2d at 163-64. Another case whose facts lend themselves to this rationale is State v. Roode, 643 S.W.2d 651, 652 (Tenn. 1982) (police in a helicopter returning from a state road project along a federally designated airway spotted acres of inarijuana).

62. United States v. Mullinex, 508 F. Supp. 512, 514 (E.D. Ky. 1980) (noting that defendant's girlfriend testified that airplane flights over defendant's farm were not unusual so that "[w]hat was exposed to police aerial surveillance was also exposed to the public"); United States v. DeBacker, 493 F. Supp. 1078, 1081 (W.D. Mich. 1980) (airplane fights over local area "not infrequent" and "[a]ny pilot, commercial or pleasure craft, might have observed the marijuana and notified the police"); State v. Bigler, 100 N.M. 515, 516, 673 P.2d 140, 141 (Ct. App. 1983) (fact that defendant's property was located near an airport and that crop dusters flew in the area obviated any reasonable expectation of privacy); State v. Rogers, 100 N.M. 517, 518, 673 P.2d 142, 143 (Ct. App. 1983) (since air traffic was not uncommon in the area, defendant had no justifiable expectation of privacy froin aerial view).

63. Williams v. State, $157 \mathrm{Ga}$. App. 476, 477, 277 S.E.2d 923, 925 (1981). See United States v. Hoskins, 735 F.2d 1006, 1008 (6th Cir. 1984) (Nichols, J., concurring) (marijuana on defendants' property seen from an airplane the same as if seen from the highway); Costello v. State, 442 So. 2d 990, 991 (Fla. Dist. Ct. App. 1983) (government officials "unquestionably had a right" to be over defendant's property when they saw marijuana, so no search occurred).

64. Another factor used by some courts is the presence of particularized suspicion of criminal activity in the area under surveillance. See United States v. Allen, 675 F.2d 1373, 1381 (9th Cir. 1980) (noting that the Coast Guard had a suspicion of drug smuggling on defendant's property), cert. denied, 454 U.S. 833 (1981); United States v. Bassford, 601 F. Supp. 1324, 1331 (D. Me. 1985) (upholding the propriety of police overfights and noting that the aerial fight was in response to "specific information concerning the cultivation of marijuana"), aff'd, 812 F.2d 16 (1st Cir. 1987). 
This broad approach grants law enforcement officials carte blanche to conduct aerial surveillance so long as they maintain an adequate altitude and do not use very advanced viewing aids. Little, if any, additional protection is afforded by the narrower approach of showing that air traffic, indeed, existed. In practice, courts have found sufficient air traffic, even in very isolated areas, to destroy the reasonableness of any privacy expectation. ${ }^{65}$ These applications of tlie open view doctrine highliglit the difficulty of asserting a constitutional right to be free from unregulated aerial surveillance. For most persons, it would be impractical to take effective steps to protect themselves from aerial observation so that, im effect, fourth ainendment rights exist only to the extent that commercial or private aircraft do not find it expedient to fly in the vicinity of one's property.

\section{Lower Court Decisions After Ohver v. United States}

As apphed to warrantless aerial surveillance, Oliver seemed to vali-

But see People v. Sneed, 32 Cal. App. 3d 535, 542, 108 Cal. Rptr. 146, 151 (1973) (police overflight in response to telephone tip reproved as "manifestly exploratory in nature"); State v. Layne, 623 S.W.2d 629, 636 (Tenn. Crim. App. 1981) (tip to officers "is of no legal significance"). That pohice are not engaged in a general search is a "factor weighed in the balance and contributes to justification for the surveillance." Allen, 675 F.2d at 1381.

This factor, however, relates not to whether there has been a search, but to whether there is sufficient cause to search. Particularized suspicion is a requirement inposed on law enforceinent officials to ensure that they have adequate reason to conduct what is already admitted to be a search. See Immigration and Naturalization Service v. Delgado, 466 U.S. 210, 224 n.6 (1984) (Powell, J., concurring) (finding in this case "no particularized suspicion is needed to justify the choice of these einployees who [were] subjected to the minimal intrusion"); United States v. Cortez, 449 U.S. 411, 417-18 (1980) (brief detention of vehicle suspected of transporting illegal aliens upheld based on prior showing that the border patrol satisfied the requirement that "the detaining officers ... have a particularized and objective basis for suspecting the particular person stopped of criminal activity"). Therefore, it is correctly used only after the surveillance is ruled a search.

Yet another factor occasionally used by courts is a "least intrusive means" test. This factor looks to whether the government agent used the least intrusive means necessary to confirm or dispel his suspicions. According to this rationale, the police officer who responds to an anonymous tip or other basis of suspicion by conducting an overflight is sinply attempting to do his job "in as nonobtrusive a way as possible." United States v. DeBacker, 493 F. Supp. 1078, 1081 (W.D. Mich. 1980).

This arguinent also muddles the justification for conducting a search with the determination of whether there was a search. The amount of discretion exercised by police in conducting a search is irrelevant in assessing whether their actions constitute a search, though it is crucial to assessing whether the search is reasonable. For example, in Florida v. Royer, 460 U.S. 491 (1983), all inembers of the Supreine Court agreed that the narcotic officers' detention of the defendant while walking through an airport was a seizure. What was disputed was the majority's view that the seizure was impermissible since the conduct was more intrusive than necessary to effectuate the purpose of the stop.

65. See, e.g., United States v. Bassford, 601 F. Supp. 1324 (D. Me. 1985), aff'd, 812 F.2d 16 (1st Cir. 1987) (rural property located in Maime where nearest neighbors were one-half inile away); State v. Stachler, 58 Haw. 412, 570 P.2d 1323 (1977) (property located near abandoned coffee farms and a forest preserve in a sparsely populated and remote area of the island of Hawain). 
date the approach of courts that relied on Hester. ${ }^{66}$ The Court itself in Oliver suggested that warrantless aerial surveillance of the land in question would have been lawful. ${ }^{67}$ Indeed, the Court's juxtaposition of curtilage with open fields suggests that a landowner can claim no fourth amendment protection for aerial surveillance of areas outside the curtilage. ${ }^{68}$ This has, in fact, been the approach of lower courts in cases decided after Oliver. Areas denominated open fields rather than curtilage have not received fourth amendment protection from police overflights. ${ }^{69}$

However, if courts consider the area viewed as within the curtilage, they continue to use a reasonable expectation of privacy analysis, though with vastly different emphases. In People v. Cook ${ }^{70}$ and People v. Ciraolo, ${ }^{71}$ the courts focused on the significant privacy interest inherent in the curtilage in holding warrantless aerial surveillance to be an unconstitutional search. These courts did so even though the manner of surveillance was not otherwise mtrusive and even though nongovernment aircraft flew overhead, thus exposing the curtilage areas to public view. ${ }^{72}$

In marked contrast, the court in United States $v$. Bassford ${ }^{73}$ refused to differentiate between curtilage and noncurtilage areas. The court stated that even if a plot of land was within the curtilage, its surveillance was not a search since "there would appear to be no sound basis for distinguishing between 'curtilage' and 'noncurtilage' areas equally visible

66. See supra note 33.

67. "[B]oth . . . Oliver and ... Thornton concede that the public and police lawfully may survey lands from the air." 466 U.S. at 179 (citation omitted). "In practical terms ... Oliver's and Thornton's analysis merely would require law enforcement officials, in most situations, to use aerial surveillance to gather the information necessary to obtain a warrant or justify warrantless entry onto the property." Id. at 179 n.9.

68. Neglecting to provide guidance for determining what constitutes curtilage, the Court noted that it was "[not] necessary . . . to consider the scope of the curtilage exception to the open fields doctrine." Id. at $180 \mathrm{n} .11$. The Court apparently believed the distinction between curtilage and open fields would be readily ascertained. "[F]or most homes, the boundaries of the curtilage will be clearly marked; and the conception defining the curtilage-as the area around the home to which the activity of home life extends-is a familiar one easily understood from our daily experience." Id. at 182 n.12.

In the wake of Oliver, one commentator derived a test to distinguish between curtilage and open fields by using a "reasonable distance" test. Comment, Curtilage or Open Fields?: Oliver v. United States Gives Renewed Significance to the Concept of Curtilage in Fourth Amendment Analysis, 46 U. PITr. L. REv. 795, 817 (1985). This test would add together the length, widtly, and lieight of a building to arrive at a figure that would create a rebuttable presumption as to thic extent of the building's curtilage. Id. at 817-18.

69. See Dow Chemical Co. v. United States, 749 F.2d 307, 312-13 (6th Cir. 1984) (open spaces between buildings in an industrial complex), aff'd, 106 S. Ct. 1819 (1986); United States v. Hoskins, 735 F.2d 1006 (6th Cir. 1984) (plot of land 100 yards away from defendant's home); United States v. Marbury, 732 F.2d 390 (5th Cir. 1984) (large gravel pit).

70. 41 Cal. 3d 373, 710 P.2d 299, 221 Cal. Rptr. 499 (1985).

71. 161 Cal. App. 3d 1081, 208 Cal. Rptr. 93 (1984), rev'd, 106 S. Ct. 1809 (1986).

72. Cook, 41 Cal. 3d at 377, 382, 710 P.2d at 301, 305, 221 Cal. Rptr. at 501, 505; Ciraolo, 161 Cal. App. 3d at 1089, $208 \mathrm{Cal}$. Rptr. at 97.

73. 601 F. Supp. 1324 (D. Me. 1985), aff'd, 812 F.2d 16 (1st Cir. 1987). 
from the air."74 The court did not believe that Oliver necessitated a different result. Although Oliver had distinguished between open fields and curtilage, it "did not delineate the scope of the curtilage exception to the open fields doctrine nor did it speak to the propriety of aerial surveillance of areas within the curtilage but open to view from the air."75

In a very perplexing decision, the court in Randall v. State ${ }^{76}$ allowed the aerial surveillance of the backyard of defendant's duplex apartment. The court agreed that the defendant had a reasonable expectation of privacy in the curtilage of his home, but concluded that the aerial surveillance comported with the open view doctrine and was not sufficiently intrusive to amount to an "impermissible search." to require a warrant "in the instant case would [not] significantly. advance the protection of legitimate privacy interests." "78 Yet the court failed to recognize that application of the open view doctrine means there is no reasonable expectation of privacy. ${ }^{79}$

\section{The Supreme Court's Aerial Surveillance Decisions}

The U.S. Supreme Court finally addressed the issue of warrantless aerial surveillance in two recent cases, California v. Ciraolo ${ }^{80}$ and Dow Chemical Co. y. United States. ${ }^{81}$ Unfortunately, these decisions only add to the confusion of how to carry out the spirit of Katz.

In Ciraolo, the Court reversed a California appellate court decision that employed the distinction between curtilage and open fields to hold that a warrantless overflight was an unconstitutional search. An officer had received an anonymous tip alleging that the defendant was growing marijuana in his backyard. The officer could not check the tip's veracity from the ground because a six-foot outer fence and ten-foot inner fence enclosed the yard. The officer, therefore, conducted a warrantless overflight from an altitude of 1000 feet, which enabled him to identify by naked-eye observation marijuana growing in a 15 by 25 foot section of the defendant's backyard.

Before addressing these facts, the Court reaffirmed its statement in Oliver that "[t]he touchstone of Fourth Amendment analysis" is the Katz reasonable expectation of privacy test. ${ }^{82}$ The Court then proceeded to use the expansive "open view" approach to find that the overfight

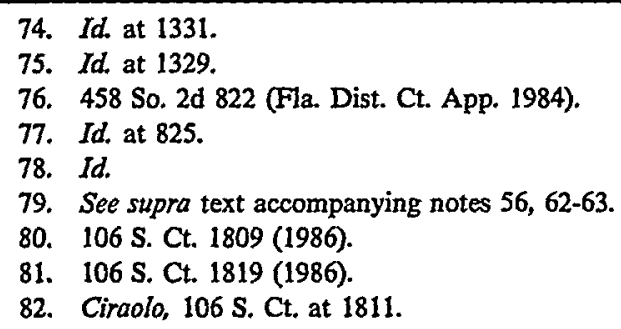

82. Ciroolo, $106 \mathrm{~S}$. Ct. at 1811. 
occurred in "public navigable airspace" and "in a physically nonintrusive manner."83 As a result, the officer viewed only what is visible to any member of the public flying in this airspace. The Court did recognize that Justice Harlan's concurrence in Katz warned of the danger of physically nonintrusive surveillance. Yet, the Court chose to limit this warning to "electronic developments," rendering it inapplicable to what it considered "simple visual observations from a public place" from which the defendant could have no reasonable expectation of privacy. ${ }^{84}$

The state appellate court liad noted that the backyard was within the curtilage. However, the Supreme Court found this inconsequential under its expansive open view analysis. The officer's observations, made from what the Court analogized to "public thoroughfares," could not violate fourth amendment rights. ${ }^{85}$

This analysis seems to confirm the Bassford court's view that the curtilage doctrine is inapplicable to aerial surveillance. ${ }^{86}$ Nevertheless, in the companion case to Ciraolo, Dow Chemical Co. v. United States, ${ }^{87}$ the Court used the distinction between curtilage and open fields to rule that the EPA's aerial pliotography of Dow's cliemical plant did not constitute a search. By analogizing the open areas of an industrial complex to an open fleld rather than the curtilage of a home, the Court placed these areas beyond the purview of the fourth amendment. ${ }^{88}$

Apparently, the distinction between curtilage and open fields was applied in Dow Chemical because the EPA used sophisticated aerial photography that revealed much nore than could be seen with the naked eye. ${ }^{89}$ Such technology renioved the surveillance from the category of views accessible to the public. Presunably, if the EPA liad relied on naked-eye observation from a physically nonintrusive height, the Court would have applied the reasoning in Ciraolo. ${ }^{90}$ However, the Court did not explicitly draw this distinction. Instead, it analyzed Ciraolo under the open view rationale and then relied on the distinction between curtilage and open fields. ${ }^{91}$

83. Id. at 1813. The Court recently denied certiorari in a case involving a 400 -foot overflight, thus allowing another California appellate court's ruling of an unconstitutional search to stand. See People v. Sabo, 185 Cal. App. 3d 845, 230 Cal. Rptr. 170 (1986), cert. denied, 107 S. Ct. 2200 (1987).

84. Ciraolo, $106 \mathrm{~S}$. Ct. at 1813.

85. Id. at 1812.

86. See supra text accompanying notes 73-74.

87. 106 S. Ct. 1819 (1986).

88. Id. at 1827 .

89. Id. at 1829 (Powell, J., dissenting).

90. The Court did note that Dow Chemical presented "two additional claims" not present in Ciraolo: "Whether the common-law 'curtilage' doctrine encompasses a large industrial complex such as Dow's and whether photography employing an aerial mapping camera is permissible in this context." Id. at 1825. The Court then proceeded to decide the case by answering these questions. Id. at $1825-27$.

91. The Court has not provided guidelines as to what constitutes a nonintrusive height. In 
To sum up the Court's guidelines for aerial surveillance, naked-eye observations from a physically nonintrusive height do not implicate fourth amendment interests. If devices that enhance vision are used in the overflight, however, fourth amendment rights may be implicated. Even so, to claim fourth amendment protection, the landowner must show that the surveillance did not occur in what are considered "open fields" under traditional property analysis.

\section{II}

\section{CRITICISM OF THE SUPREME COURT's FOURTH AMENDMENT DECISIONS}

This brief review of the judiciary's treatment of warrantless aerial surveillance reveals how troublesome the issue has been. Before Oliver, courts differed as to whether and under what circumstances areas labeled open fields could receive fourth amendment protection. While the Supreme Court in Oliver ended this largely academic query ${ }^{92}$ by denying open fields any fourth amendment protection at all, courts still needed to consider aerial surveillance of property within the curtilage, which required the additional determination of what separates curtilage from open fields. In addressing this issue, courts reached different conclusions based on their different analyses of how to apply the Katz reasonable expectation of privacy standard. In its recent rulings, the Supreme Court has finally given guidelines on applying the fourth amendinent to warrantless aerial surveillance. Although it acknowledges that Katz embodies the essence of fourth amendment jurisprudence, the Court rehes on property concepts to delineate the extent of fourth amendment privacy rights. The Court seems to assume that property interests determine whether expectations of privacy are reasonable. ,

Ciraolo, the Court emphasized that the police aircraft maintained an altitude of 1000 feet, placing it in "public navigable airspace." $106 \mathrm{~S}$. Ct. at 1813.

Under federal regulations setting minimum safe altitudes for all aircraft, fixed-wing aircraft may fly at an altitude of 1000 feet over congested areas and 500 feet over other areas. No definite minimum height is set for helicopters; they must simply operate "without hazard" to persons and property on the ground. 14 C.F.R. $\S 91.79$ (1987).

Based on the Court's reasoning that what the public can view is not proteeted by the fourth anendment, these minimum altitudes for aircraft may determine what is a physically nonintrusive height for government aerial surveillance. If so, the property owner has very hittle protection. If the government employs a hehicopter to view the landowner's property, the government violates no fourth alnendment rights unless its helicopter poses a physical hazard to the landowner or his property. See California v. Sabo, 107 S. Ct. 2200, 2201 (1987) (White, J., dissenting from denial of certiorari) (where a helicopter hovered 400-500 feet above defendant's property, Justice White believed that the helicopter exception in the federal rules meant no search oceurred as the helicopter, even if below navigable airspace, was lawfully positioned).

92. In fact, in every instance where land has fit the "open field" description, it has been denied fourth amendment proteetion, whether the open field doctrine or a version of the Katz test was used. 


\section{A. The Problem with the Distinction Between Curtilage and the Open Fields Doctrine}

Prior to Katz, the Supreme Court generally adhered to the "constitutionally protected areas" approach in determining the scope of fourth amendment rights. ${ }^{93}$ Under this standard, a physical intrusion of some sort into a constitutionally protected area was necessary to trigger the application of the amendment. ${ }^{94}$ Hence, an intrusion which did not effect a physical trespass ${ }^{95}$ was not a fourth amendment search. Under this rationale, it would appear that "the eye cannot commit" a search. ${ }^{96}$ Indeed, im pre-Katz cases discussimg bimocular-aided vision, the Court stated that such observations were not prohibited by the Constitution. ${ }^{97}$

The advent of the Katz reasonable expectation of privacy test was widely held to repudiate this narrow view in favor of a broader, more flexible approach. ${ }^{98}$ The Court's decision in Oliver, however, has been criticized as constricting the breadth of fourth amendment protection and as regressing towards the narrower pre-Katz reading of the fourth amendment. ${ }^{99}$

In fact, the majority in Oliver did affirm Justice Harlan's reasonable expectation of privacy standard. ${ }^{100}$ Yet at the same time, the majority found the open fields rule to be "founded upon the explicit language of the Fourth Amendment" and noted that the "Amendinent indicates with some precision the places and things encompassed by its protections."101 After making this poimt, the majority considered and rejected the possi-

93. Silverman v. United States, 365 U.S. 505, 512 (1961) (placement of a "spike" mike in a house implicated the fourth amendment); see Amsterdam, supra note 41, at 357. This phrase first appeared in Judge Frank's dissent in United States v. On Lee, 193 F.2d 306, 314 (2d Cir. 1951), aff'd, 343 U.S. 747 (1952).

94. Silverman, 365 U.S. at 512. See Olmstead v. United States, 277 U.S. 438,466 (1928) (fourth amendment not violated unless there is an official search and seizure of one's person, papers, effects or "an actual physical mvasion of his house 'or curtilage' for the purpose of making a seizure").

95. Under the common law, trespass was defined as "[a]n unlawful interference with one's person, property, or rights." BLACK's LAw DICTIONARY 1347 (5th ed. 1979). "Every unauthorized and direct breach of the boundaries of another's land" comprises a trespass of real property. Id.

96. McDonald v. United States, 335 U.S. 451, 454 (1948). The Court noted this was the government's position without approving or rejecting it.

97. See On Lee v. United States, 343 U.S. 747, 754 (1952); United States v. Lee, 274 U.S. 559, 563 (1927) ("[The] use of a searchlight is comparable to the use of a marine glass or a field glass. It is not prohibited by the Constitution."); see also Amsterdam, supra notc 41, at 381.

98. See, e.g., The Supreme Court, 1967 Term, 82 HARv. L. REv. 63, 188-90 (1968); Note, From Private Places to Personal Privacy: A Post-Katz Study of Fottrh Amendment Protection, 43 N.Y.U. L. REV. 968, 975-78 (1968).

99. See Justice Marshall's dissent im Oliver, 466 U.S. 170, 187-88 (1984); see also Comment, The Shrinking of the Fourth Amendment Umbrella: Oliver v. United States, 9 Nova L.J. 231 (1984); Note, Oliver v. United States: Open Fields and Reasonable Expectations of Privacy, 1985 UTAH L. REv. 463.

100. 466 U.S. at 177.

101. Id. at 176. 
bility that the drafters intended open fields to be within the meaning of "effects." 102 This analysis is reminiscent of the pre-Katz approach in its focus on whether the area itself is within the definition of "persons, houses, papers and effects," or to put it another way, whether the area is a "constitutionally protected" one. As the dissent in Oliver noted, there is a tension between this analysis and the analysis suggested by Katz and developed by its progeny. ${ }^{103}$

The Oliver Court purported to reconcile the open fields rule with Katz by determining that there are no reasonable privacy expectations inherent in open fields. The Court claimed there is no "societal interest" in protecting privacy in open fields since these fields, by their very character, do not provide the setting for activities protected by the fourth aniendment. ${ }^{104}$ In contrast, the curtilage is intimately associated with home life and family privacy. ${ }^{105}$

The problem with the Court's reasoning lies in its attempt to limit the fluid concept of privacy rights envisioned by Katz to rigid, historical notions of what constitute fourth amendment rights. By holding "that no expectation of privacy legitimately attaches to open fields,"106 the Court ignored factual variations and legitimate societal values.

For example, in Oliver the Court defined open fields by referring to the common law curtilage distinction. Open fields "nuay include any unoccupied or undeveloped area outside of the curtilage. An open field need be neither 'open' nor a 'field' as those terms are used in common speech."107 Therefore, despite the efforts of an individual to insure the private enjoyment of his property, he has no fourth amendinent right to be free froin government intrusion if such property is outside the curtilage.

In a pre-Oliver decision, State v. Brady, ${ }^{108}$ the Florida Suprenie Court found that a property owner's reasonable expectation of privacy was violated where "[i]n order to position surveillance groups around the

102. Id. at 177 .

103. Id. at 188 \& nn.6-7 (Marshall, J., dissenting). In addition, the dissent derides the majority's reliance npon a literal reading of the fourth amendment, noting that under this approach the curtilage itself should not come under fourth amendment protection, being (as are open fields) neither a house nor an effect. The dissent also cites several previous instances in which the Court has extended protection to objects not within the literal meaning of the amendment's language. Id. at 185-86.

104. Id. at 179 .

105. Id. at 180, 182 n.12; $c$ f. Dow Chenrical Co. v. Urited States, 106 S. Ct. 1819, 1825 (1986) ("The intimate activities associated with family privacy and the home and its cnrtilage ... do not reach the outdoor areas or spaces between structures and buildings of a manufacturing plant.").

106. Oliver, 466 U.S. at 180.

107. Id. at $180 \mathrm{n} .11$.

108. 406 So. 2d 1093 (Fla. 1981), cert. denied in part, judgment vacated in part, 467 U.S. 1201 (1984). 
ranch's airfield, deputies were forced to cross a dike, ram through one gate and cut the chain lock on another, cut or cross posted fences, and proceed several hundred yards to their hiding places."109 After Oliver, the U.S. Supreme Court vacated this decision, reinanding the case for consideration in light of Oliver. ${ }^{10}$ The Florida Supreme Court then reversed itself, ruling that Oliver validated this "open field" search, and consequently defendants could not suppress evidence gathered in the search at issue. ${ }^{111}$

In addition, the inajority's reasoning in Oliver would accord no societal interest to a landowner's reservation of a small portion of his property for solitude and meditation or for religious worship. In every instance, the fourth amendment right to privacy ends abruptly with the curtilage, which is defined as "the land immediately surrounding and associated with the hoine." 112 Though some parts of Oliver described the curtilage in terms that suggest a definition capable of encompassing the reservation of land for solitude and ineditation, ${ }^{113}$ the inajority apparently did not intend such a broad notion. The majority belittled the dissent's complaint that law enforcement officials might intrude on 'lovers' trysts and worship services."114 The majority was content to rely on lower court decisions defining the curtilage "by reference to the factors that determine whether an individual reasonably may expect that an area immediately adjacent to the hoine will remain private." 115

As the inajority noted, the curtilage distinction at least seems to provide government agents with clear guidance as to what is and what is not

109. Id. at 1094-95.

110. Florida v. Brady, 467 U.S. 1201 (1984).

111. 466 So. 2d 1064, 1064-65 (Fla. 1985); see Oliver, 466 U.S. at 196-97 (Marshall, J., dissenting) (quoting United States v. Lace, 669 F.2d 46, 54 (2nd Cir. 1982) (Newman, J., concurring)) (noting that the majority's decision implicitly approved prior cases such as Lace, which held it " 'reasonable" " for "police officers [to] execute military maneuvers on residential property for three weeks of round-the-clock surveillance").

112. Oliver, 466 U.S. at 180.

113. See id. (quoting Boyd v. United States, 116 U.S. 616, 630 (1886)) ("the area to which extends the intimate activity associated with the 'sanctity of a man's hoine and the privacies of life,' "); Id. at 182 n.12 ("the area around the home to which the activity of home life extends").

114. Id. at 179 n.10.

115. Id. at 180 (emphasis added). The majority cited three circuit court eases that discussed the extent of the curtilage. In United States v. Van Dyke, the court found that the officers' presence 15 fect within a fence and 150 feet from a house infringed upon the curtilage, which was defined as "an area of domestic use immediately surrounding a dwelling and usually but not always fenced in with a dwelling." 643 F.2d 992, 993 n.1 (4th Cir. 1981) (quoting United States v. LaBerge, 267 F. Supp. 686, 692 (D. Md. 1967)). In United States v. Williams, a shed 50 yards from the house was within the curtilage, which the court defined as including the "lome and its immediate appurtenances." 581 F.2d 451, 453 (5th Cir. 1978) (quoting Hodges v. United States, 243 F.2d 281, 283 (5th Cir. 1957)), cert denied, 440 U.S. 972 (1979). In Care v. United States, the court held that a cave located a "long city block from the home" was not within the curtilage. 231 F.2d 22, 25 (10th Cir.), cert. denied, 351 U.S. 932 (1956). 
permissible. ${ }^{116}$ However, the distinction may not in fact aid an agent in determining the scope of his authority. What if this landowner builds a small cottage or shrine on land away from his hoine for worship or ineditation? Would this create a new curtilage, and hence, a protected area? If so, would the area immediately surrounding this building also be considered curtilage? What about other outbuildings, such as a greenhouse, tool shed, barn or an outhouse?

Another host of probleins concerns how far to extend the curtilage. Should the length of the curtilage vary with the number of inhabitants or with the purpose for which the building is used? ${ }^{117}$

These definitional probleins suggest that, contrary to the Court's implication in Oliver, adherence to the curtilage distinction may not ease a police officer's task of discerning constitutional limitations imposed by the fourth amendment. ${ }^{118}$ Furthermore, by making fourth amendinent analysis dependent on a prior determination of what geographical perinutations constitute curtilage, Oliver reintroduces the artificial distinctions that Katz sought to eliminate by repudiating the protected areas approach.

The Court's atteinpt to supermipose its reading of Hester onto Katz reveals another difficulty. While relying heavily on the common law distinction between curtilage and open fields, the Court inexplicably disregarded the common law trespass doctrine, which is crucial to property law. ${ }^{119}$

In implicitly discounting the importance of trespass law, the Court quoted the stateinent in Katz that "[t] he premise that property interests control tlie right of the Governinent to search and seize has been discredited" 120 so that now "a property right is but one element in determining whether expectations of privacy are legitimate."121 The Oliver Court's application of the fourtl amendment, lowever, turned on a property law

116. Oliver, 466 U.S. at 182 n.12.

117. One recent commentator considered only the size of the building-adding together the length, width, and height of a building - to arrive at a rebuttable presumption as to what is the curtilage. See Comment, supra note 68 , at 817.

118. 466 U.S. at 181.

119. According to Blackstone, "[t] $]$ respass, in its largest and most extensive sense, signifies any transgression or offense against the law of nature, of society, or of the country in which we live; whether it relates to a man's person or his property." $3 \mathrm{~W}$. BLACKSTONE, supra note 6, at *208. At common law, trespass of land was regarded as legally actionable, "even though the invasion caused no harm and even though the defendant was not at fault in causing the invasion." D. DOBBs, $R$. KeEton \& D. OWen, Prosser aND KeEton ON TORTS 67 (W. Keeton 5th ed. 1984). Coinparing the relative importance of the concepts of trespass and curtilage, one would expect the Court in its review of the conmon law to give greater weight to the trespassory nature of government intrusions, rather than to focus on the comparatively minor import of the distinction between curtilage and open n̂elds.

120. 466 U.S. at 183 (quoting Katz v. United States, 389 U.S. 347, 353 (1968)).

121. Id. at 183 . 
distinction between curtilage and open fields. Reasonable privacy expectations may inhere in the curtilage; they are per se excluded from open fields. In support of its distinction, the Court cited Blackstone's Commentaries. ${ }^{122}$ Yet, the Commentaries used this distinction to define the common law offense of burglary, a property crime. ${ }^{123}$ Surely the Court erred in believing that "th[is] [common law] distinction implies that only the curtilage, not the neighboring open fields, warrants the Fourth Amendment protections."124 The Court's willingness to wed the fourth amendment to the distinction between curtilage and open fields belies its own admonition that property concepts are not controlling.

\section{B. The Fallacy of the Open Fields/Open View Argument}

In Dow Chemical, the Court purported to apply the distinction between curtilage and open fields. ${ }^{125}$ However, the importance of this distinction is severely undercut by the Court's adoption of the open view argument in Ciraolo. ${ }^{126}$ Aerial surveillance is a technological development which lays open curtilage and noncurtilage areas alike to governinent observation. From the perspective of aerial overflights, there would seem to be no distinction in observability between curtilage and noncurtilage areas. ${ }^{127}$ Given that Oliver precludes any reasonable expectation of privacy in open fields and that any distinction between open fields and curtilage is nullified by the openness of both areas to aerial view, the curtilage cannot be the object of a reasonable expectation of privacy, at least privacy from aerial surveillance. A landowner must realize that his property, whether withm or outside the curtilage, is open to aerial observation. Under this analysis, the curtilage as well as open fields do not deserve fourth amendment protection from aerial surveillance. This conclusion is consistent with Oliver which, while extolling the privileged status of the curtilage, at the same time undercut the import of recognizing such a status, statimg in a footnote that it "is ... [not] necessary in [tliis case] to consider ... the degree of Fourtli Amendment protection afforded the curtilage ...."128 Therefore, it is conceivable that the curtilage inay be protected from physical intrusions but not from pliysically nonintrusive overflights. In short, the curtilage distinction seems superfluous in the context of aerial surveillance.

\footnotetext{
122. Id. at $\mathbf{1 8 0 .}$

123. One element necessary for burglary at common law was that it be a burglary of a requisite "place." The curtilage disinction was used to determine whether this condition had been met. $4 \mathrm{~W}$. Blackstone, supra note 6 , at $* 225$.

124. 466 U.S. at 180.

125. Dow Chemical Co. v. Umited States, 106 S. Ct. 1819, 1825-27 (1986).

126. California v. Ciraolo, 106 S. Ct. 1809, 1812-13 (1986).

127. See supra text accompanying note 74 .

128. 466 U.S. at 180 n.11.
} 
In Ciraolo, the Court did not explicitly draw this conclusion. It relied instead on the assuinption that the fourth amendinent does not apply where the area is viewed from whit is considered a "public vantage point." 129 This facile conclusion presupposes that there can be no basis for distinction between areas viewed from a physically nonintrusive height. This, in turn, rests upon the assumption that as long as an area is open in some manner to public view, no reasonable expectation of privacy can attacli to that area from any observations made in the saine manner. The openness of property to public view was central to the Court's rationale for affirming the open fields rule in Oliver. ${ }^{130}$ By regarding the sky as a public thoroughfare, the Court, $m$ effect, employed its open fields rationale to overcome the curtilage barrier for overflights.

Nevertlieless, the Court in Dow Chemical retained some use for the curtilage/open fields distinction to regulate overflights that einploy vision enhancing devices not commonly used by the public. As noted earlier, ${ }^{131}$ the logic seems to be that the enhanced observations made reveal that which cannot be seen by tlie fiying public, thereby implicating the fourth amendment. ${ }^{132}$ Yet these observations are subject to fourth amendment restrictions only if they are made within tlie curtilage. ${ }^{133}$

129. $106 \mathrm{~S} . \mathrm{Ct}$. at 1812 .

130. Accessibility to public view, however, was only one basis for upholding the open fields rule. The other consideration was that, unlike the curtilage, intimate family activities generally do not take place in open fields. See supra note 28. Yet the Court does not address the effect of its ruling on this concern.

131. See supra text accoinpanying note 89 .

132. One criticisin of this position is that the public can obtain these views by the expedient of using the same vision-enhancing devices. For example, in Dow Chemical, the government employed an aerial mapping camera whose photographs could be inagnified to reveal objects one-half inch in diameter. 106 S. Ct. at 1827 n.5. Far from being "highly sophisticated surveillance equipment not generally available to the public," this was a "commercial camera commonly used in map-Inaking." Id. at 1826. Hence, the public could have seen what the EPA observed. In fact, there is every reason to believe that certain meinbers of the public-namely, Dow's coinpetitors-would like very inuclı to obtain the same views. That such viewing inay contravene existing trade secret laws does not change the fact that the EPA's observations conld be made by the public.

133. The Court noted that the employment of super-sophisticated viewing devices not generally available to the public, sucli as satellite teclinology, would require closer review, perliaps necessitating the procurement of a warrant. Id. at 1826. A warrant may be needed even though the area viewed is not within the curtilage, apparently because such a sophisticated device could allow observations within physical structures, inuch like bugging devices that can penetrate walls. Id. at 1826-27. This would imply a three-tier level of review in aerial surveillance cases. At the first level, naked-eye aerial overflights are not permitted when they are so low as to pliysieally intrude into a landowner's airspace. See, e.g., People v. Sabo, 185 Cal. App. 3d 845, 230 Cal. Rptr. 170 (1986), cert. denied, 107 S. Ct. 2200 (1987) (overflight and circling of defendant's backyard at 400 feet impermissible without a warrant); People v. Sneed, 32 Cal. App. 3d 535, 543, 108 Cal. Rptr. 146, 151 (1973) (observations made from a lielicopter 20 to 25 feet above defendant's property constituted an unreasonable government intrusion). At the next level, viewing aids tliat enhance human vision may pose a constitutional problem. But see Dow Chemical, 106 S. Ct. at 1827 (use of camera by law enforcement officials in an aerial observation of defendant's property not an unconstitutional search). Finally, equipment not generally available to the public that permits observation in far grcater detail 
Dow Chemical and Ciraolo narrowly circumscribe the already slender protection afforded by the Court's revival of the distinction between curtilage and open fields. Despite its rhetoric in Oliver, the Court is, in fact, willing to provide only minimal protection to curtilage areas. As long as government agents obtain an aircraft and refram from using overly sophisticated viewing devices or from fiying at a physically intrusive height, they can freely monitor all of one's property.

Though Ciraolo and Dow Chemical undermine the importance of Oliver, these cases are consistent with Oliver in that they, too, proceed from a misapprehension of the proper role of property concepts. In Oliver, the Court found it convement to take one aspect of property law, the distinction between curtilage and the open fields, and apply it mecharically to find no reasonable expectation of privacy. This deprived the property owners of fourth amendment protections. ${ }^{134}$ In Ciraolo and Dow Chemical, the court treated the protection alloted property rights as an end rather than a means for ensuring broader privacy rights, thus allowing the defeat of property protections by aerial surveillance to defeat privacy rights as well.

In its aerial surveillance decisions, the Court adopted the open view argument that areas accessible to public view cannot be the object of a reasonable expectation of privacy. In other words, if property protections are meffective agamst the public, they hikewise do not preclude government observation. Under this analysis, however, a landowner's fourth amendinent riglits will continue to shrink as society employs technological advancements. For exainple, the distinction between curtilage and open fields in Oliver seened to grant a landowner privacy rights in the curtilage, whatever area thiat might include. But this property distinction proved meffective agamst aerial views in Ciraolo, so no privacy rights could be claimed. Nevertheless, the Court in Dow Chemical believed this distinction could still be of service in regulating overflights that use sophisticated vision-enhancing devices, since the public did not generally use such equipment. Presumably, however, if in tle future the public were conmonly to use similar sophisticated devices, ${ }^{135}$ this property distinction would no longer apply, and attendant fourtl amendment rights would vamisli. ${ }^{136}$

than what can ordinarily be seen even with viewing aids may require a warrant even though the area viewed is not within the curtilage. See id. at 1826.

134. See infra text accompanying notes 156-66.

135. If commonly used, such devices would cease to be considered "sophisticated," much as airplane fiights are now considered routine occurrences. See California v. Ciraolo, 106 S. Ct. 1809, 1813 (1986) (aerial surveillance described as "simple visual observations from a public place").

136. One could hardly think of a better example to illustrate Justice Harlan's admonition that technological developments should not be allowed to constrict fourth amendment protections. To swecp aside this problem by claiming that Justice Harlan's observations were limited to "future 
The end result of Oliver, Ciraolo, and Dow Chemical is to circumscribe the Katz reasonable expectation of privacy test. By ruling that privacy expectations in certain parts of a landowner's property are per se unreasonable despite any conceivable factual permutations, the Court returns to the talismanic approach repudiated in Katz. In short, these decisions represent a movement away from the Katz rationale.

\section{The Value of Property Concepts}

The Court neglects to recognize that adherence to Katz better serves the purpose that animated the use of property concepts in fourth amendment law. Indeed, Katz was intended to serve the same purpose; to guarantee the individual a certain anount of autonomy vis-à-vis the state.

\section{The Locke-ian Philosophy of Property Rights}

In drafting the Constitution, the framers were influenced by Lockeian philosophy, which links property concepts to individual liberty and well-being. ${ }^{137}$ For Locke, property is a natural, inherent right. The fundainental example of property is the individual's body to which "nobody has any right . . . but himself." 138 Locke derives this primordial instance of property from his examination of the state of nature, that hypothetical state preceding the formation of civil governments. In this state, a person is an autonomous self, at perfect liberty, free from any restraints imposed by government. ${ }^{139}$ His property is limited to his body. There is as yet no ownership of external things, what is commonly thought of as property. External things are potentially for anyone, but initially are the property of no one. This state of nature is conceived by Locke as a "state of no-ownership." 140

To turn external things into property requires mixing one's labor (what is "inine") with the external things. By so exerting labor upon objects found in nature, a person removes them from the "common state." He changes things which were not yet any one person's property into his property, thus "exclud[ing] the coinmon right of other men [to make use of such objects]." 141

Property so understood involves autonomy; that which is "mine"

\footnotetext{
'electronic' developments" such as bugging devices, Ciraolo, $106 \mathrm{~S}$. Ct. at 1813, is a literal reading of the case that, in effect, repudiates Katz. As the dissent in Ciraolo pointed out, "[r]eliance on the manner of surveillance is directly contrary to the standard of Katz, which identifies a constitutionally protected privacy right by focusing on the interests of the individual and of a free society." $106 \mathrm{~S}$. Ct. at 1817 (Powell, J., dissenting).

137. Hamilton, Property-According to Locke, 41 YALE L.J. 864, 873-74 (1932).

138. J. Locke, The Second Treatise of Government $\S 27$ (T. Peardon ed. 1952) (1690).

139. Id. $\S 44$.

140. A. Ryan, Property and Political Theory 30 (1984).

141. J. LOCKE, supra note 138 , at $\S 27$.
} 
necessarily excludes the claims of others. It is consistent that Locke elsewhere defines property as "lives, liberties and estates."142 Property encompasses "lives, liberties and estates" because they are that to which one has an exclusive (or natural) riglit. Properly conceived, they cannot be infringed upon without one's consent. ${ }^{143}$

Yet, the enjoyment of such freedom is precarious in the state of nature due to the potential "invasion of others."144 Hence, paradoxically, people have formed societies with laws to insure the preservation of their individual liberties. The chief end of government, therefore, "is the preservation of tlieir property"145 to guarantee the life, liberty and estate of the individual. That this should be a central concern of government appeared self-evident to the frainers. ${ }^{146}$ For them, the purpose of law, particularly the fourth amendment, ${ }^{147}$ was to protect these property rights, to insure their reservation to the individual free from the intrusion of oppressive government. One commentator has noted:

The institution called property guards the troubled boundary between individual man and the state. ${ }^{148}$ Property draws a circle around the activities of each private individual. . . . Outside, he inust justify or explain his actions, and show his authority. Within, he is inaster, and the state must explain and justify any interference. ${ }^{149}$

The early landmark case on the fourth amendment, Boyd v. United States, ${ }^{150}$ adopted this Lockeian reasoning. The Court quoted at great length from Lord Camden's opmion in the famous Enghish case of Entick v. Carrington, ${ }^{151}$ in which he declared:

The great end, for which men entered into society was to secure their property. That right is preserved sacred and incoininunicable in all instances, where it has not been taken away or abridged by soine public law for the good of the whole. ... By the laws of England, every invasion of private property, be it ever so ininute, is a trespass. No inan can set his foot upon my ground without my hicense, but he is liable to an action though the damage be nothing. ${ }^{152}$

According to the Boyd Court, "[t] he principles laid down in [Entick] affect the very essence of constitutional liberty and security" and "apply

\footnotetext{
142. Id. $\S 123$.

143. See id. $\S 193$.

144. Id. $\$ 123$.

145. Id. $\S 124$.

146. See C. Merriam, A History of American Political Theories 61-63 (1918).

147. See Boyd v. United States, 116 U.S. 616, 626-27 (1886) (asserting that the drafters of the fourth amendment considered the understanding of common law property rights "as sufficiently explanatory of what was meant by unreasonable searches and seizures").

148. Reich, The New Property, 73 Y ALE L.J. 733, 733 (1964).

149. Id. at 771 .

150. 116 U.S. 616 (1886).

151. 19 Howell's State Trial 1029 (1765).

152. Boyd, 116 U.S. at 627 (quoting Entick, 19 HowELL's STATE TRIAL at 1066).
} 
to all invasions on the part of the government and its employees of the sanctity of a man's home and the privacies of life," for such government searches invade one's "imdefeasible right of personal security, personal liberty and private property." 153

Nevertheless, the Court never equated fourth amendment rights with property law. The Court employed property concepts as a crucial factor in developing the constitutionally protected areas standard but recognized the purpose of the fourth amendment was to secure one's right to be "free from unreasonable governmental imtrusion." 154 Hence, the Court has not used the exacting standard of Entick. Yet, the Lockeian property concepts which underhe the amendment also underlie the protected areas standard. In each instance, property rights are employed to limit the government's ability to intrude upon mdividual privacy and autonomy.

\section{The Relation of Property Rights to Katz}

Likewise, the Katz formulation of reasonable expectations of privacy is an attempt to preserve mdividual autonomy agamst encroacliment by the state. It is not expressed in property terms because technological developments, specifically the sophistication of electromic bugging devices, have rendered the privacy guarantees of property rights inadequate. In an era when technology extends the state's ability to intrude upon personal privacy to a degree beyond the contemplation of Locke or the framers, the contimued reliance on property interests is indeed, "bad physics as well as bad law."155 Katz is, therefore, not so much a divergence from property law concepts as an attempt to adhere to the purpose of common law property rights.

In relation to the fourth amendment, Katz and property rights serve the same function of preserving the legal right of the individual to be an autonomous actor in a society by protectimg him from unreasonable government intrusion. ${ }^{156}$ Their different formulations stem from their different historical context. For Locke and through the beginning of this century, property rights adequately guaranteed personal freedom vis-àvis the state. In this century, scientific advancements have outstripped the security provided by property law. It is precisely to remain true to the purpose of property law that the Court in Katz expresses itself in non-property terms.

It is important to note that the bamishment of property law from

153. Id. at 630 .

154. Silverman v. United States, 365 U.S. 505, 511 (1961).

155. Katz y. United States, 389 U.S. 347, 362 (1967) (Harlan, J., concurring).

156. For an article stressing the individual's need for privacy from the state in order to beconie a well-developed person, see Fried, Privacy, 77 YALE L.J. 475 (1968). 
Fourth Amendment jurisprudence is not a necessary corollary of Katz. Property rights are certainly useful in determining whether a reasonable expectation of privacy exists. Property, as Locke tells us, entails the exclusion of others and, hence, the reservation for exclusive use. ${ }^{157}$ This right of exclusion, however, is never absolute but subject to limitations imposed by society for the common good. Yet, these limitations do not abolish the right to exclude, they merely temper it. For example, a person's property imterest in his home has long been accorded the highest deference. ${ }^{158}$ Nevertheless, if a louse in a neighborlood were to catch fire, the owner would not be able to exclude firemen from entering his lome to extinguish the blaze. ${ }^{159}$ In the same manner, a property interest may be evidence of a reasonable expectation of privacy under the fourth amendment; it is simply not conclusive evidence. This is no remarkable proposition, and the Court in Oliver did acknowledge it. ${ }^{160}$ But it failed to heed it.

In Oliver and Dow Chemical, the Court returned to a reliance on property terminology. Yet, the Court cannot fully reconcile its use of the - common law distinction between curtilage and open fields in aerial surveillance witl the Katz test merely througl1 the incantation of "societal interests," 161 because the Court's uncritical application of 18th century property law concepts misconceives the raison d'etre of these concepts. As Ciraolo inakes evident, property law principles are incapable of preserving individual freedom from the state. They are thus inappropriate guides for delineating the scope of fourtl amendment protection. To be consistent with the historic purpose of property concepts, courts must adopt tlie Katz test. ${ }^{162}$

157. J. LOCKE, supra note 138 , at $\$ 27$.

158. See N. Lasson, The History and Development of the Fourth Amendment to THE UNITED STATES CONSTITUTION 34 n.78, 49-50, $123-24$ (2d ed. 1970).

159. See, e.g., Michigan v. Tyler, 436 U.S. 499 (1978). In Tyler, a burning building represented an exigency enabling firefighters to enter the building without a warrant to extinguish the blaze and to remain after dousing the flames for a reasonable time in order to investigate the cause of the fire. Id. at 509-10. However, warrantless entries by fire inspectors five weeks later were not pursuant to the initial exigency and therefore were invalid as a warrantless fourth anendment search. Id. at 511 .

160. Oliver v. United States, 466 U.S. 170, 183 \& nn.14-15 (1984); see also Rakas v. Illinois, 439 U.S. 128, 143-44 n.12 (1978) ("Expectations of privacy protected by the Fourth Amendment, of course, need not be based on a common-law interest in real or personal property or on the invasion of such an interest.").

161. See supra notes $104-05$ and accompanying text.

162. The reasonable expectation of privacy test is a necessary consequence of the fourth amendment, but it is not the only possible consequence. Other theories could be used. Commentators have proposed alterations of this test to ensure amendment protection for privacy expectations, relying not on reasonableness but on a sense of entitlement or on a claim of right. Amsterdain, supra note 41, at 385; Note, $A$ Reconsideration of the Katz Expectation of Privacy Test, 76 MiCH. L. REV. 154 (1977).

It is also possible to redefine property concepts in a manner that would allow their continued use in fourth amendinent jurisprudence. For example, a Hegelian notion of property would not 


\section{III \\ A Proper Application of Fourth AMENDMENT \\ PRINCIPLES: OBEDIENCE TO $K A T Z$ AND THE Purpose of Property Rights}

Careful reflection on the interests of the individual and of a free society would have disclosed the debilitating effect of granting the police broad discretion in using aerial surveillance to momitor the outdoor activities of citizens im an enclosed curtilage. A proper apphication of the Katz reasonable expectation of privacy test would take seriously the threat to privacy interests posed by police overflights. The result of such an analysis would be the development of consistent, rational guidelines for determining when areas are afforded fourth ainendinent protection from aerial surveillance.

Aerial surveillance is precisely the type of activity to which $\mathrm{Katz}$ was meant to apply. As is the case with wiretapping, property law concepts are madequate guarantees of personal privacy and security when confronted by this modern method of observation. It is necessary to apply Katz, therefore, to remain faithful to the framers' intent that the fourth amendment serve as a bulwark against unreasonable governinent intrusions.

The initial determination of what values are to be accorded fourth amendment protection - that is, what is considered a reasonable expectation of privacy - cannot be discerned from the language of the amendinent itself. ${ }^{163}$ Prior to Katz, the answer to this question had principally been sought im property law concepts. ${ }^{164}$ Katz shifted the emphasis to notions of societal interests, that is, "understandings . . recognized and permitted by society." 165 By referring to established societal customs as a basis for fourth alnendment rights, courts ought to be better equipped to safeguard fourth ainendment rights from evolving technologies.

The Katz test also recognizes these rights are not absolute but rela-

suffer from Locke's focus on the right to exclude others as the sine qua non of property. For Hegel, property rights are premised on the subject's control of the object possessed, rather than the individual's right to exclude others. A. RYAN, supra note 140, at 122-23. The need to protect property rights can be understood as part of the dialectic, the process by which Hegel understands history. G. Hegel, The Philosophy of History 17-20 (1956). According to the dialectic, Spirit, the fullness of existence, must act on its opposite, matter, that which is absolute nihility, to come into existence. Individuals are important because they provide the means by which Spirit acts on matter to come into existence. Under this view, the fact that prohibitions on physical trespass fail to prevent government intrusion need not eviscerate one's fourth amendment rights. Property rights are violated whenever government activity unreasonably impairs one's ability to use his possessions. This unwarranted interference by the state retards the dialectical process between subject and object, thereby hindering Spirit in its process of self-actualization.

163. See, e.g., supra notes $40-65$ and aceompanying text.

164. See supra notes $153-58$ and accompanying text.

165. Rakas v. Illinois, 439 U.S. 128, 144 n.12 (1978). 
tive to the public interest in a well-ordered and law-abiding society. The court is called upon to determine when these personal values of privacy and security denominated as rights outweigh societal interests in effective law enforceinent, and how best to protect these values in light of these societal interests. Thus, to apply Katz to aerial surveillance, it must first be determined that the personal values associated with the area, whether it be labeled open fields or curtilage, enjoy the status of fourth ainendinent rights. ${ }^{166}$

\section{A. The Chilling Effect of Aerial Surveillance on the Enjoyment of Fourth Amendment Rights}

Differentiation between private and government observation proinotes the protection of fourth ainendinent privacy rights. These rights foster a sense of security ${ }^{167}$ and personal freedoin ${ }^{168}$ by supplementing property law concepts when they prove inadequate. ${ }^{169}$

As discussed above, ${ }^{170}$ property concepts have been of preeminent importance in constitutional history because of the Lockeian perception that property reserves to the individual a sphere in which he reigns supreine, free from undeserved intrusions of others. Unfortunately, technological developinents such as wiretapping and aerial surveillance frustrate the autonomy previously provided by property concepts by exposing the details of peoples' private activities to government agents. In thwarting privacy rights protected by property rights, government surveillance has a chilling effect on personal security and individual autonomy, values at the core of the fourth amendinent and, indeed, the entire Bill of Rights. ${ }^{171}$

This privacy clain is not the freedom from surveillance that a lawbreaker desires, but the "right to be let alone"172 that every citizen in a free society values and needs. ${ }^{173}$ In fact, it is the einphasis not only on an

166. The open view argument would seem to suggest that they do not, because if the area is exposed to the public, the owner can have no reasonable expectation that government agents will not also view the area. What the open view argument fails to recognize is the distinction between the privacy expectations of different classes of people_-in particular, law enforcement officials and other segments of society.

167. See United States v. United States Dist. Court, 407 U.S. 297, 312 (1972); Alderman v. Umited States, 394 U.S. 165, 175.(1969); United States v. White, 401 U.S. 745, 786 (1971) (Harlan, J., dissenting).

168. See Rakas, 439 U.S. at 151 (Powell, J., concurring).

169. See supra text accompanying notes $150-60$.

170. See supra text accompanying notes 137-58.

171. See LASSON, supra note 158, at 86-99; see also United States Dist. Court, 407 U.S. at 312-13 (1972) (discussing the government's duty under the Bill of Rights to safeguard the security of its people).

172. See Olmstead v. United States, 277 U.S. 438, 478 (1928) (Brandeis, J., dissenting); see also Warren \& Brandeis, The Right to Privacy, 4 HARv. L. REV. 193, 193 (1890).

173. See Fried, supra note 156 at $477,490$. 
individual's freedom to go and do what he wants, but his freedom to do so without government supervision that distinguishes denocratic societies from totalitarian regimes. ${ }^{174}$ This right to enjoy the intinacies of one's life free from government scrutiny inheres especially in the home and curtilage, but may be present in areas beyond the curtilage. ${ }^{175}$ As such, a property owner'inay be able to claim an objectively reasonable expectation of privacy froin unregulated, warrantless government aerial surveillance.

Contrary to what has been said in opinions that have focused on the manner of surveillance-that there is no fourth amendment search for overflights that are considered "inobtrusive," 176 - the chilling effect of government surveillance is not dissipated inerely because the government does not engage in continuous, overt surveillance. The sinuple fact that the state has the power to inonitor the private activities of property owners at its whim violates a reasonable privacy interest. If anything, surveillance may be even inore invidious when it is surreptitiously conducted. Appeals to law enforcement niterests to validate such "minor" intrusions ${ }^{177}$ should be viewed in hight of the Court's warning that heightening the efficiency of law enforceinent by the use of some technique "can never by itself justify disregard of the Fourth Amendment." 178

\section{B. Establishing a Reasonable Expectation of Privacy from Aerial Surveillance}

Though a property owner inay have a legitiniate or reasonable expectation of privacy from warrantless aerial surveillance, whether this is in fact the case in a particular instance will depend on the underlying facts. Rather than relying on rigid rules, faithful adherence to Katz requires the maintenance of flexibility in fourth amendinent analysis. ${ }^{179}$

In determming whether a party has a reasonable expectation of privacy, the central consideration should be the ineasures taken to prevent ground-based intrusions. If a property owner takes steps to assert his

174. See A. Westin, Privacy AND Freedom 23-24 (1967) ("The modern totalitarian state relies on secrecy for the regime, but high surveillance and disclosure for all other groups. . . The democratic society rehes on publicity as a control over government, and on privacy as a shield for group and individual hfe.").

175. For a discussion of when privacy rights may extend beyond the curtilage, see infra text accompanying notes $180-87$.

176. See supra notes 47-55 and accompanying text.

177. See United States v. DeBacker, 493 F. Supp. 1078, 1081 (W.D. Mich. 1980) (defendant had a "relatively minor expectatio[n] of privacy" from aerial surveillance of his farm at an altitude of 50 fect); People v. Joubert, 118 Cal. App. 3d 637, 646, 173 Cal. Rptr. 428, 434 (1981) ("[A]nyone who grows marijuana in the open today does so at the risk of beiug spotted by flying police officers.").

178. Mincey v. Arizona, 437 U.S. 385, 393 (1978).

179. See Amsterdam, supra note 41 , at 385 . 
intention to exclude persons from looking in and trespassing onto his property, he has, according to understandings long recognized and permitted by society, a reasonable expectation of privacy in the enjoyment of his land. ${ }^{180}$

Generally, a property owner will take greater ineasures of exclusion with regard to curtilage areas. This is the true inport of the curtilage distinction. It is not a bright line between reasonable and unreasonable expectations of privacy but a general indication of which expectations are inore likely to be reasonable. Yet, it is possible in some situations that measures taken to insulate noncurtilage areas from public view should be sufficient to establish a reasonable expectation of privacy in those areas.

For example, in Dow Chemical Co. v. United States, ${ }^{181}$ the Environmental Protection Agency inade aerial overflights to obtain detailed photographs of Dow's industrial complex, thus thwarting extensive security measures taken by Dow against ground-based intrusions. As one basis for its decision, the court relied on the open fields rule to deny Dow's claim to fourth amendment protection. ${ }^{182}$ Under a proper Katz analysis, however, the fact that Dow built a security fence around its property and einployed security guards ${ }^{183}$ would be of greater weight in assessing the inerit of Dow's fourth amendment clain than the designation of the property viewed.

By taking extensive steps to secure its property from intrusions by others, Dow evinced an intent in Lockeian terms to reinove the property froin the "coininon state" 184 for its private use. Inherent in the law of trespass ${ }^{185}$ and, in the very concept of private property as Locke asserts, ${ }^{186}$ is the societal recognition that Dow's protection of its property lines is a manifestation of its intent and right to exclude others. By asserting its rights as a property owner, Dow, therefore, gave notice of its intent to reserve its complex for private use, and society, through its trespass laws and general recoguition of property rights, implicitly acquiesced in the reasonableness of this expectation. Aerial surveillance of Dow's complex, though not teclinically an infringeinent on Dow's prop-

180. This proposition is not new; more than one commentator has made this suggestion. See, eg., Comment, supra note 56, at 483; Comment, Warrantless Aerial Surveillance: $A$ Constitutional Analysis, 35 VAND. L. REV. 409, 434-35 (1982). But courts have not agreed. Supra note 46 and accompanying text.

181. 749 F.2d 307 (6th Cir. 1984), aff'd, 106 S. C. 1819 (1986).

182. Id. at 313-14. The court also relied on the open view argument to find that the ground level protection measures did not indicate a privacy interest in protection from aerial surveillance. Id. at $312-13$.

183. Id. at 312 .

184. See supra text accompanying note 141 .

185. Recall Lord Camden's statement quoted in Boyd v. United States. See supra text accompanying notes $150-57$.

186. See supra text accompanying notes 145-53. 
erty rights, frustrates the reasonable privacy expectations that these property rights sought to insure.

In certain situations where law enforcement officials have a special need to keep an area under aerial surveillance, measures taken to prevent ground-based intrusions may be inadequate to guarantee protection from aerial surveillance. For example, in United States v. Allen, ${ }^{187}$ Coast Guard helicopters routinely traversed private property on the Oregon coast as part of their "well-known function of sea-coast patrol and surveillance." ${ }^{188}$ Under these circumstances, the defendants could not reasonably expect that evidence of their criminal activity would not be noticed by officers in a Coast Guard hehicopter. ${ }^{189}$

In most cases, however, a property owner's upkeep and fencing of his property should suffice to establish the reasonable expectation that his property will not be scrutinized by law enforcement officials in aircraft hovering overhead. The sky is not a road for fourth amendment purposes. To justify police surveillance on the basis that members of the public can and do on occasion glance down while flying overhead is to fail to distinguish between reasonable privacy expectations from government and private intrusions, thereby subjecting landowners to the chilling effect of government surveillance.

\section{Differing Privacy Expectations Depending on Who is the Intruder}

Observations made by law enforcement agents are quahtatively different from observations inade by the public in their effect on an individual's perception of his autonouny. Supreme Court opinions have noted this distinction. In Mancusi v. DeForte, ${ }^{190}$ the Court held a government seizure of records invalid where the defendant shared an office with fellow union inembers. The Court stated that the defendant could reasonably expect that "only those persons and their personal or business guests would enter the office, and that [union] records [kept by him] would not be touched except with their permission or that of union higher-ups." 191

187. 675 F.2d 1373 (9th Cir. 1980).

188. Id. at 1381 .

189. Id. It is important to note that Allen is a case involving the U.S. border, thereby involving government interests that have long been recognized as particularly strong. See, e.g., Montoya De Hernandez v. Umited States, 473 U.S. 531, 537-39 (1985); United States v. Villamonte-Marquez, 462 U.S. 579, 591 (1983). As such, it remains distinguishable from aerial surveillance of interior areas. To allow a general government interest in effective law enforcement to validate aerial patrols of urban and rural areas would create an exception that would swallow the rule.

190. 392 U.S. 364 (1968).

191. Id. at 369. See Justice Marshall's dissent in California Bankers Ass'n. v. Shultz, 416 U.S. $21,95-96$ (1974) ("The fact that one has disclosed private papers to the bank, for a limited purpose, within the context of a confidential customer-bank relationship, does not mean that one has waived all right to the privacy of the papers."). 
In Walter $v$. United States, ${ }^{192}$ a package was delivered to the wrong address. After opening it and judging from labels affixed to the reels that it contained pornographic movies, employees of the corporation located at that address turned the films over to the government. Concurring in the plurality opmion that a subsequent government screening of the films without a warrant was an invalid search, Justice White argued that "private searches [do not] imsulate from Fourth Amendment scrutiny subsequent governmental searches of the same or lesser scope" so that the government "may [not] conduct the same kind of search that private parties have conducted without implicating Fourth Amendment interests."193

Lower courts have also recognized the difference between police and private observations. In Piazolla v. Watkins ${ }^{194}$ and Commonwealth $v$. McCloskey, ${ }^{195}$ the fact that university officials reserved the right to check the dormitory rooms of college students did not mean police could search the rooms without a warrant. In both cases, the courts realized that students may have different privacy expectations depending on the purpose of the intrusion or the identity of the intruders. ${ }^{196}$

In State v. Stanton, ${ }^{197}$ though the warrantless search of defendant's field was found not to violate the defendant's fourth amendment rights, ${ }^{198}$ the court affirmed that:

while it may not be objectively reasonable for a person to expect privacy as to one class of persons or persons with one purpose, he may reasonably expect privacy as to the same or other classes with other purposes. A person may not expect privacy in his open field or backyard as against children at play or parents looking for lost or tardy children. Yet he may subjectively expect and objectively be entitled to expect privacy as against policemen making a "dragnet" search . . . . 199

In aerial surveillance cases, the open view argument, unlike $K a t z$,

192. 447 U.S. 649 (1980) (plurality opinion).

193. Id. at 660-61. The plurality opinion held the search invalid because it found the government screening to exceed the scope of the private search. This meant that the government did not simply receive the fruits of a private search but conducted an entirely new search that required independent grounds for justification. Id. at 656-57. As to the problem of relying on private intrusions to justify subsequent goverument intrusions, see infra text accompanying notes 203-05.

194. 442 F.2d 284 (5th Cir. 1971).

195. 217 Pa. Super. 432, 272 A.2d 271 (1970).

196. Piazolla, 442 F.2d at 289-90; McCloskey, 217 Pa. Super. at 435-36, 272 A.2d at 272-73.

197. 7 Or. App. 286, 490 P.2d 1274 (1971), overruled in part, State v. Walle, 52 Or. App. 963, 630 P.2d 377 (1981).

198. The court held that the defendant had no objectively reasonable expectation of privacy since an uncultivated plot of land, criss-crossed by fences that were not recognizable as property lines was "designed more to kecp livestock under control than to keep people out." 7 Or. App. at 296,490 P.2d at 1279.

199. Id. at 296-97, 490 P.2d at 1279; see also Umited States v. Lace, 669 F.2d 46, 57 (2d Cir.), cert. denied, 459 U.S. 854 (1982) (Newman, J., concurring) ("[R]isking observation by a limited category of persons is not the equivalent of public exposure and does not displace a reasonable 
does not take into account the objection that a glance by a private citizen is qualitatively different from observation conducted by government agents. As the California Supreine Court has recognized, though commercial overflights inay be prevalent and members of the public may on occasion glance down, a property owner can reasonably expect that governinent agents, absent a warrant, will not scrutinize his yard. ${ }^{200}$ When a person barbecues or gardens in his backyard, he does not contemplate that overhead aircraft are disclosing to the public the intimate details of his activities. Quite the opposite, he may reasonably expect to conduct his activities in comfortable privacy. This reasonable expectation arises because, in fact, such indiscreet observations are not made. The sky may indeed be a "public thoroughfare,"201 but unlike a road, travelers generally do not view in any detail the property they are passing. This understanding is implicit in Katz, which holds that what a person "seeks to preserve as private, even in an area accessible to the public, may be constitutionally protected."202

Although recognizing the distinction between expectations as to government intrusions and intrusions by private parties, the Court often fails to give it any force. Indeed, the Court has held that a search of property by a private party obviates any fourth amendment protection the owner of the property would otherwise have. In United States $v$. Jacobsen, ${ }^{203}$ the defendant mailed a package via Federal Express that was dainaged en route. Federal Express employees opened the package pursuant to company pohicy regarding insurance claims. Inside, they found a tube, which they cut open to reveal about six ounces of white powder wrapped in plastic bags. After replacing the bags in the tube and putting the tube in its original package, they contacted the Drug Enforcement Agency (DEA). A DEA agent subsequently arrived and, without obtaining a warrant, reopened the package. He then took the bags out of the tube and obtained samples of the white powder, which, when tested, was found to be cocame.

In approving the agent's reopening of the package, the majority found no privacy interest violated since the agent's inspection enabled hin to "learn nothing that had not previously been learned during the private search."204 Disagreeing on this point, Justice White noted that

expectation of privacy against 'governmental intrusion.' ") (citing Mancusi v. DeForte, 392 U.S. 364, 368 (1968)).

200. See People v. Cook, 41 Cal. 3d 373, 377, 382 \& n.3, 710 P.2d 299, 301-02, 304 \& n.3, 221 Cal. Rptr. 499, 501, 504 \& n.3 (1985); People v. Sabo, 185 Cal. App. 3d 845, 230 Cal. Rptr. 170 (1986), cert. denied, 107 S. Ct. 2200 (1987).

201. See supra text accoinpanying note 85 .

202. Katz v. United States, 389 U.S. 347, $351-52$ (1967).

203. 466 U.S. 109 (1984).

204. Id. at 120. With regard to the agent's testing of the powder, the Court recognized that the 
"the fact that a repository of personal property previously was searched by a private party has never been used to legitimize governmental conduct that otherwise would be subject to challenge under the Fourth Amendment."205

Justice White was troubled by the implications of the majority's approach. Carried to its logical conclusion, the majority's reasoning would seem to allow a government official to conduct a warrantless search based on a tip consisting of firsthand observations by a private party that the official beheved estabhished probable cause. The effect of the majority's decision was to permit a government official to search the defendant's property without a warrant because of information gained from the employees. In putting the bags back into the tube and the tube into the package, the einployees unwittingly removed the incriminating evidence from the plain view of the agent. In reopening the package and extracting the bags, the agent conducted his own search. ${ }^{206}$

The foundation for the decision in Jacobsen was laid in United States v. Miller, ${ }^{207}$ where the Court held that a defendant had no fourth amendment right in checks, deposit shps, and financial statements he gave to his bank. Hence, this information could be subpoenaed by the governinent. According to the Court:

The depositor takes the risk, in revealing his affairs to another, that the information will be conveyed by that person to the Governinent. . . . [T] he Fourth Amendinent does not prohibit the obtaining of information revealed to a third party and conveyed by hin to Government authorities, even if the information is revealed on the assuinption that it will be used only for a limited purpose and the confidence placed in the third party will not be betrayed. ${ }^{208}$

Soon after Miller, the Court apphed this same reasoming in Smith v.

results would reveal information not previously uncovered by the employees. Yet the Court found that the chemical test "[did] not compromise any legitimate interest in privacy" since the government's conduct could reveal only "whether a substance is cocaine, and no other arguably "private' fact...." Id. at 123.

205. Id. at 130-31 (White, J., concurring). Note that Justice White's position was consistent with his concurrence in Walter v. United States, 447 U.S. 649 (1980), in which he distinguished governmental searches from private ones. See supra text accompanying notes 192-97.

206. Given these facts, Justice White said he "would be hard-pressed" to distinguish this situation from:

(1) one in which the private party's knowledge, later communieated to the government, that a particular container concealed contraband and nothing else arose from his presence at the time the container was scaled; (2) one in which the private party learned that a container concealed contraband and nothing else when it was previously opened in his presence; or (3) one in which the private party knew to a certainty that a container concealed contraband and nothing else as a result of conversations with its owner.

Jacobsen, 466 U.S. at 133.

207. 425 U.S. 435 (1976).

208. Id. at 443 . 
Maryland. ${ }^{209}$ There, the Court held that a pen register installed at the government's request did not violate the defendant's fourth amendment rights. The Court stated that the defendant had no legitimate expectation of privacy $\mathrm{m}$ the numbers he dialed from a phone in his home. The Court reasoned that in using the phone, the defendant "voluntarily conveyed" the information to the phone company and, therefore, "assumed the risk that the company would reveal to potice the numbers he dialed."210

Justice Stewart's dissent in Smith pointed out the extent of this intrusion authorized by the Court. Far from being "without 'content," " the dissent observed that the listing of telephone numbers obtained by the police "easily could reveal the identities of the persons and the places called, and thus reveal the most intimate details of a person's life."211

Underlying the dissatisfaction of the concurrences and dissents in Miller, Smith, and Jacobsen is the concern that the majority ignores reasonable expectations people have that a government intrusion will be treated differently from a similar private intrusion. To adhere to the majority's reasoning im each of these cases by denying private property fourth amendment protection from aerial surveillance would allow technology to eviscerate fourth amendment rights. This would be contrary to the intent of Katz, which responded to the danger technology posed to personal rights.

\section{Invoking the Warrant Restrictions}

Having determined that a person can reasonably expect that activities on his property will not be monitored by the "eye in the sky," government aerial surveillance that intrudes on that expectation becomes a fourth amendment search. What remains to be decided is the extent of fourth amendment protection afforded this expectation.

Subject to specific, liimited exceptions, ${ }^{212}$ fourth amendment searches require a warrant. ${ }^{213}$ Aerial surveillance of property in which the owner has established a reasonable expectation of privacy by posting no trespassing signs and building fences or otherwise taking steps to protect his property from ground-based intrusions is a searcli. Therefore, the property owner should be able to invoke the protection of the warrant restrictions to regulate such searches.

209. 442 U.S. 735 (1979).

210. Id. at 744 .

211. Id. at 748 (Stewart, J., dissenting).

212. See, e.g., Chimel v. California, 395 U.S. 752 (1969) (searches incident to arrest); Terry v. Ohio, 392 U.S. 1 (1968) ("stop and frisk" searches); Carrol v. United States, 267 U.S. 132 (1925) (car searches).

213. United States v. United States Dist. Court, 407 U.S. 297, 315-18 (1972); Katz v. United States, 389 U.S. 347, 356-57 (1967). 
The warrant requirement protects the property owner by interposing the "deliberate, impartial judgment of a judicial officer."214 As a general rule, warrants for a search or a seizure may be obtamed only upon a showing of probable cause. ${ }^{215}$ The magistrate provides a check on police whose perception of what constitutes probable cause is colored by their "engage[ment] $\mathrm{m}$ the often competitive enterprise of ferreting out crime."216 Furthermore, an officer seeking a warrant must establish a record prior to its issuance. ${ }^{217}$ This ensures that police will not be tempted to proceed with an unreasonable search or seizure in the liope of obtaining additional evidence to justify their original decision to search. ${ }^{218}$

This precept of fourth amendment law has not always been followed by courts in warrantless aerial surveillance cases. In Randall $v$. State, ${ }^{219}$ the court admitted that the defendant had a reasonable expectation of privacy in his backyard. However, the court allowed the warrantless aerial search simce it was considered not unduly intrusive, and the court could see no significant benefit resulting from requiring a warrant. ${ }^{220}$ Such an approach not only fails to follow proper fourth amendment procedure, it imvites those "silent approaches and slight deviations" by which "illegitimate and unconstitutional practices get their first footimg."221

\section{E. Relaxation of the Warrant Requirement}

There are two instances in which aerial searches could be permitted,

214. Katz, 389 U.S. at 357 (quoting Wong Sun v. United States, 371 U.S. 471, 481 (1963)).

215. The fourth amendinent provides in part that: "[No] warrants shall issue, but upon probable cause, supported by Oath or affirmation, and particularly describing the place to be searched, and the person or things to be seized." U.S. CoNST. amend. IV; see United States v. Harris, 403 U.S. 573, 577-80 (1971) (evaluating "the showing of probable cause necessary to support a search warrant"); Henry v. United States, 361 U.S. 98, 100 (1959) (The fourth amendinent "command[s] ... that no warrants for either searches or arrests shall issue except upon 'probable cause.'").

However, in the context of adıninistrative inspections and other regulatory searches, courts have authorized the issuance of warrants on evidence that would not amount to probable cause in the context of regular criminal law enforcement. See infra notes 224-30 and acconupanying text.

216. Johnson v. United States, 333 U.S. 10, 14 (1948).

217. The fourth amendinent conditions the issuance of a warrant on the support of an "Oath" or "affirmation" and the particular description of the place to be searched and persons or things to be seized. See supra note 215 .

218. In Whiteley v. Warden, 401 U.S. 560 (1971), the Suprene Court rejected a sheriff's attempt to use the fruits of a search to bootstrap a warrant obtained without probable cause. The Court noted: "Under the cases of this Court, an otherwise insufficient affidavit cannot be rehabilitated by testinony concerning information possessed by the affiant when he sought the warrant but not disclosed to the issuing inagistrate... A contrary rule would, of course, render the warrant requirements of the Fourth Amendinent meaningless." Id. at 565 n.8 (citation onitted).

219. 458 So. 2d 822 (Fla. Dist. Ct. App. 1984).

220. Id. at 825 .

221. Boyd v. United States, 116 U.S. 616, 635 (1886). 
though conducted without a warrant or with a warrant that is not based on probable cause. Warrantless aerial searches could be permitted under a special "plain view" exception. Using the reasoning of the plain view doctrine set forth in Coolidge v. New Hampshire, ${ }^{222}$ where a government agent is otherwise properly conducting an aerial overflight, an inadvertent glance which reveals criminal activity should be permitted as an exception to the warrant requirement. ${ }^{223}$ In these cases, the reason for disallowing warrantless government aerial surveillance-its chilling effect on the enjoyment of privacy-is absent. The issue of whether a 'glance' was truly inadvertent would require a judicial examination of the particular facts.

Warrants issued on less than probable cause that authorize aerial searches could be allowed by analogizing the situation to that encountered in Camara v. Municipal Court. ${ }^{224}$ In Camara, the defendant had refused to allow city housing authorities to enter his home to conduct a warrantless inspection for housing code violations. The Court upheld the defendant's refusal, stating that an imtrusion into the defendant's premises constituted a fourth amendment search, requiring administrative officials to obtain a warrant. 225

In discussing the type of warrant needed for an "administrative" search, the Court indicated that a lesser degree of proof than is normally required in criminal imvestigations may suffice for the issuance of such a warrant: "[A]n ... official need [not] show the same kind of proof to a inagistrate to obtain a warrant as one must who would search for the fruits or instrumentalities of crime."226 The Court noted that "tlie inspections are neither personal in nature nor aimed at the discovery of crime" but "involve a relatively limited invasion of the urban citizen's privacy."227 These statements may suggest that the Court was distinguishing between searches ained at criminal prosecution and administrative searches. But a more plausable view would be that a lesser amount of evidence is necessary im this less intensive search than in searches generally permitted in criminal investigations. ${ }^{228}$

As has been shown, Katz interprets the fourth amendment as necessitating the protection of reasonable privacy expectations. These expectations can be violated as thoroughly by an administrative search as by a

222. 403 U.S. 443 (1971) (plurality opinion); see supra notes 57-61 and accompanying text.

223. See supra cases discussed in notes 59-61 and accompanying text.

224. 387 U.S. 523 (1967); see also See v. City of Seattle, 387 U.S. 541 (1967) (area warrant necessary for inspection of commercial structures by fire department officials).

225. 387 U.S. at 540 .

226. Id. at 538 (quoting Frank v. Maryland, 359 U.S. 360, 383 (1959) (Douglas, J., dissenting)).

227. Id. at 537 .

228. See 3 W. LAFAVE, supra note $8, \S 10.1(b)$, at 607-08. 
search aimed at criminal prosecution. ${ }^{229}$ Indeed, the Court in Camara recognized that:

Like most regulatory laws, fire, health, and housing codes are enforced by criminal processes. In some cities, discovery of a violation . . . produces only an administrative conpliance order, refusal to comply is a criminal offense, and the fact of compliance is verified by a second inspection, again without a warrant. ${ }^{230}$

In fact, the defendant in Camara was facing a criminal charge for refusing to permit the imspection. ${ }^{231}$

Nevertheless, the Court recognized that the special nature of such searches allowed for the issuance of warrants on less than probable cause. Of crucial importance in mitigating the effect on privacy rights was the existence of "reasonable legislative or administrative standards for conducting an area inspection."232 Such standards gnard against the arbitrary exercise of the authority to search by regulating the manner and scope of surveillance. Restrictions include requiring searches to be conducted at a convenient time of day, ${ }^{233}$ delineating the specific places that can be searched, ${ }^{234}$ severely constricting the time within which the warrant must be executed, ${ }^{235}$ and prohibiting forcible entry of homes except in special cases. ${ }^{236}$

Balanced agamst the intrusion upon the individual's privacy and personal security is the state lawmaker's interest in protecting health and welfare of society so that "[t]here is unanimous agreement ... that the only effective way to seek universal compliance with the minimum standards required by municipal codes is through routine periodic inspection

229. For example, in Abel v. United States, 362 U.S. 217 (1960), an INS agent's search of defendant's hotel room did not implicate the fourth amendment because its fruits werc not used as evidence of crime but instead as evidence of his deportability. Yet, as one commentator noted, "[a] more exhaustive search is hardly to be found in the records of the Supreme Court." J. LANDYNSKI, SEARCh AND SEIzURE IN THE SuPREME CourT 258 (1966).

230. 387 U.S. at 531 (footnotes omitted).

231. Id. at 525 .

232. Id. at 538; see id. at 532-33 (criticizing the present administrative system, which by "leav[ing] the occupant subject to the discretion of the official in the field . . . [allows] precisely the discretion to invade private property which we have consistently circumscribed by a requirement that a disinterested party warrant the need to search.").

233. See Cal. Civ. Proc. CODE $\S 1822.56$ (West 1982) (search must be between 8 a.m. and 6 p.m.); N.J. STAT. ANN. § 24:21-32(a) (West Supp. 1986) (search to be conducted "during normal business hours").

234. N.J. StaT. ANN. § 24:21-32(b) (West Supp. 1986).

235. In North Carolina and North Dakota, the warrant must be executed within 24 hours of its issuance. N.C. GEN. STAT. § 15-27.2(d)(1) (1983); N.D. CENT. CODE § 29-29.1-04 (1974). But see Cal. Civ. Proc. Code $\S 1822.55$ (West 1982) (warrant good for two weeks after its issuance).

236. Cal. Civ. Proc. CODE $\S 1822.56$ (West 1982) (an inspection cannot be made by forcible entry unless facts show "a reasonable suspicion of a violation of a . . law or regulation . . . which . . . would be an immediate thrcat to health or safety, or where facts are shown establishing that reasonable attempts to serve a previous warrant have been unsuccessful"). 
of all structures."237 Because such inspections are "unavoidably based on ... appraisal ... of conditions in the area as a whole, not on [the] knowledge of conditions in each particular building,"238 the "public interest" necessitates that area warrants be issued as the only "acceptable" method of ensuring compliance. ${ }^{239}$

The concerns in Camara are analogous to problems confronting law enforcement officials in rural areas. While the state has a special interest in eradicating the large-scale cultivation of marijuana prevalent in secluded rural areas, large tracts of property in these localities remain impervious to ground-based observation. ${ }^{240}$ On the other hand, property owners in these regions retain a reasonable expectation of privacy from unregulated aerial surveillance. In fact, by inhabiting such secluded areas, they mamifest their desire for privacy. Furthermore, as mentioned earlier, overfliglits can be used as a means for harassinent. ${ }^{241}$

These competing interests could be accommodated by autliorizing area warrants based loosely on municipal imspections authorized by Camara. The procedures could seek to minimize tlie government's intrusion by setting limits on tlie duration and frequency of overfliglits, as well as the scope of the area viewed. In addition, they could specify a mimimum altitude and restrict the use of viewing aids in order to minimize the extent to which details of hunran activity are observed. ${ }^{242}$

In this manner, tlie mdividual would not be subject to the discretion of the officer in tlie field. Requiring aerial searches to survive standards imposed and overseen by a neutral and detaclied magistrate would circumscribe the capacity for abuse of aerial surveillance and ensure only a minimal intrusion of reasonable privacy expectations. In turn, law

237. Camara v. Municipal Court, 387 U.S. 523, 535-36 (1967) (footnote omitted).

238. Id. at 536 (footnote omitted).

239. Id. at 537; see Note, The Fourth Amendment and Housing Inspections, 77 YALE L.J. 521, 525-26 (1968) (finding "the undeniably strong police power policy of ensuring the healthfulness and safety of dwellings, and the unavailability of equally efficient substitutes for general area-wide inspections to enforce that policy" to sanction the minimal intrusion occasioned by housing inspections).

240. See People v. Mayoff, 42 Cal. 3d 1302, 1309, 729 P.2d 166, 169, 233 Cal. Rptr. 2, 5 (1986) (joint state-federal program in Cahforina to stem the cultivation of marijuana operates in "extremely rugged and isolated ... territory so remote that it can be examined only from the air").

241. See National Org. for Reforn of Marijuana Laws v. Mullen, 608 F. Supp. 945 (N.D. Cal. 1985). In response to reports of abuses by the state's marijuana eradication program, the district court issued an injunction setting altitudes above which law enforcement helicopters must fiy when they are withm a certain radius of curtilage areas. This ease, following Oliver, left noncurtilage areas unregulated.

242. See Mayoff, 42 Cal. 3d at 1316 n.6, 729 P.2d at 174 n.6, 233 Cal. Rptr. at 10 n.6. In holding that the warrantless surveillance of open fields is not a search, the court nevertheless "establish[ed] the principle that the aircraft must maintain a visual distance sufficient to obscure the details of human activity below" and that "[o]ptical enhancers may not be used to shorten the visual distance." 
enforcement officials would retain a badly needed tool in their struggle to eradicate marijuana.

In recently rejecting this proposal in People v. Mayoff, ${ }^{243}$ the California Supreme Court noted several difficulties with its implementation. Initially, the court reasoned that it would impose "a cumbersome twostep procedure, with one warrant necessary to permit the initial aerial surveillance, then, in most cases, another to authorize any subsequent ground search."244 It does seem two warrants would be needed if marijuana were spotted in the aerial search because the later ground search would be a different, more serious intrusion, necessitating a showing of probable cause. But this is not a bad result. The court noted that a federal court had already enjoined some of the more abusive aerial surveillance practices of the saine law enforcement program it was presently reviewing. ${ }^{245}$ If anything, this indicates the need for closer regulation of aerial surveillance in these situations. Recognizing this, the court urged the legislature to provide standards for aerial surveillance operations. ${ }^{246}$ But it is the court's duty to ensure that fourth amendinent rights are protected. ${ }^{247}$

The court in Mayoff also had difficulty in ascertaining upon what evidence the inagistrate would base the issuance of a warrant. ${ }^{248}$ In Camara, the Court indicated that a warrant should be issued for an area search "if reasonable legislative or administrative standards for conducting an area inspection are satisfied with respect to a particular dwelling." 249 This indicates the limited review provided by the inagistrate. The magistrate "decide[s] whether there is an established inspection policy and whether the inspection for which authorization is sought is consistent with that policy."250

243. 42 Cal. 3d 1302, 729 P.2d 166, 233 Cal. Rptr. 2 (1986).

244. Id. at $1318 \mathrm{n} .8,729$ P.2d at 175 n.8, 233 Cal. Rptr. at $11 \mathrm{n} .8$.

245. Id. at 1318, 729 P.2d at 175, 233 Cal. Rptr. at 11. See National Org. for Reform of Marijuana Laws, 608 F. Supp. at 955-58. The federal district court quoted testimony by several persons relating their harassment by government helicopters. Among the more disturbing declarations was that of a woman who stated:

[The helicopter] was right above the tree level, right outside my house, right over iny house and at that time they tipped their helicopter several times and one of [the] times, made obscene gestures at my seven year old daughter who was on the ladder watching. Id. at 955 .

246. Mayoff, 42 Cal. 3d at 1308, 729 P.2d at 168, 233 Cal. Rptr. at 4. While the court was syinpathetic to the dangers presented by aerial surveillance, it concluded that aerial surveillance of agricultural fields was not a search as the observations were inade from a height that did not violate the minimal privacy expectations in these fields. Id. at 1315,729 P.2d at 173, 233 Cal. Rptr. at 9.

247. See Marbury v. Madison, 5 U.S. (1 Cranch) 137, 177-78 (1803). In this famous case, Justice Marshall established the principle that the judiciary rather than the legislature is entrusted with interpreting the Constitution.

248. Mayoff, 42 Cal. 3d at 1318 n.8, 729 P.2d at 175 n.8, 233 Cal. Rptr. at 11 n.8.

249. Camara v. Municipal Court, 387 U.S. 523, 538 (1967).

250. 3 W. LAFAVE, supra note $8, \S 10.1(\mathrm{c})$, at 611-12. 
The magistrate's basis for issuing a warrant in aerial surveillance prograins should be the saine. As in housing inspections, the magistrate's principal function is as a check on the arbitrariness of the search. ${ }^{251}$ In the housing situation, it is conceded that violations will occur over a given area and that they can be effectively discovered only through the use of an area warrant. Likewise, in secluded rural areas it is generally recognized that large-scale cultivation of marijuana is a serious problem which can be adequately combated only with the aid of aircraft. Therefore, the Mayoff court's concern that the magistrate will lack the inforination necessary to effectively evaluate the merit of an overflight overstates the magistrate's role. The magistrate fulfills his duty by ensuring that law enforcement officials proceed in accordance with set standards.

The Mayoff court's final concern was that the magistrate would be unable "to prejudge the infinite variations in altitude, distance, flight pattern, and air speed which might arise from conditions faced by the aircraft's pilot."252 This worry seens unnecessary. Presumably, the standards governing the conduct of aerial overflights will set general limitations within which it is the pilot's duty to operate. Much the same as a housing code may prohibit inspections before $8 \mathrm{a}$.m. or require the search to be completed within one day of the warrant's issuance, so may standards for aerial searches prescribe a minimum altitude level to be maintained at all times or set a time limit on the duration of an overflight.

\section{CONCLUSION}

The Supreme Court's uncritical use of property concepts to resolve fourth amendment aerial surveillance cases is potentially disastrous. If open fields lack any legitimate privacy interest and no rational basis exists for differentiating between open fields and curtilage areas as seen froin the air, it seems that no legitimate privacy interest attaches to any property, whether denominated curtilage or noncurtilage, if it is viewed from the air. By rendering the distinction between open fields and curtilage meaningless, aerial surveillance also seems to render ineaningless any fourth amendment rights premised on this distinction.

This constriction of the fourth aniendment need not occur, for it was precisely the inadequacy of common law property concepts to safeguard fourth amendinent riglits which led to the adoption of the Katz reasonable expectation of privacy standard. Katz was necessary to remain faitliful to the purpose of property concepts as originally envi-

251. See supra notes $232-40$ and accompanying text; see also $3 \mathrm{~W}$. LAFAve, supra note 8 , $\S 10.1$ (c), at 612 (noting that in housing inspections, "the warrant process . . . is not so much a check on unjustified searches as it is upon arbitrary searches").

252. 42 Cal. 3d at 1318 n.8, 729 P.2d at 175 n.8, 233 Cal. Rptr. at 11 n.8. 
sioned by John Locke and subsequently understood by the framers and the Court. This purpose is to ensure the maintenance of individual freedom and autonomy as against the state and is the fundamental purpose of the fourth amendment. ${ }^{253}$ These values are protected by the preservation of privacy interests. To secure these privacy interests from unwarranted aerial intrusions, however, courts should be more sensitive to the dangers posed by this method of surveillance. What is needed is a Katz analysis that acknowledges the chilling effect of government surveillance on individual liberties and enforces, except in limited circumstances, the warrant restrictions.

Tom Bush*

253. Property law protects the individual against intrusions by all of society, not just the government. The fourth amendment, however, applies only to government actions. See supra note 2.

* B.A. 1982, University of Notre Dame; M.A. 1984, Claremont Graduate School; J.D. 1987, Boalt Hall School of Law, University of California, Berkeley. 